\title{
ISLANDS OF EFFECTIVE INTERNATIONAL ADJUDICATION: CONSTRUCTING AN INTELLECTUAL PROPERTY RULE OF LAW IN THE ANDEAN COMMUNITY
}

\author{
By Laurence R. Helfer, Karen J. Alter, and M. Florencia Guerzovich*
}

Forty years ago, the small and underdeveloped nations on the mountainous western edge of South America formed a regional integration pact to promote economic growth, regulate foreign investment, and harmonize national laws. ${ }^{1}$ Overall, their enterprise has not turned out well. Riven by political schisms, economic shocks, and weak domestic legal and judicial systems, the five principal countries of the Andean Community-Bolivia, Colombia, Ecuador, Peru, and Venezuela - have failed to live up to their potential as South America's second largest trading bloc. ${ }^{2}$ The member states have relaunched the Andean integration project and revised its policies on multiple occasions, with at best only mixed results. Not surprisingly, most commentators have ignored the Andean Community or dismissed it as a failure. ${ }^{3}$

\footnotetext{
* Professor of Law and Director, International Legal Studies Program, Vanderbilt University Law School; Associate Professor of Political Science, Northwestern University; and PhD candidate, Department of Political Science, Northwestern University; respectively. We are grateful for the financial support provided by the Center for the Americas at Vanderbilt and the Northwestern Dispute Resolution Research Center, which funded field research in Quito, Lima, and Bogotá. For helpful comments, we thank Graeme Austin, David Boyd, Gabriella Blum, Rachel Brewster, Daniel Drezner, Martin Flaherty, Diana Rodríguez Franco, Darren Hawkins, Thomas Lee, Katerina Linos, Arnulf Becker Lorca, Gerald Neuman, Kal Raustiala, Osvaldo Saldías, Christopher Whytock, Ingrid Wuerth, and the participants in the Fordham International Law-International Relations Colloquium, the Harvard Law School Faculty Workshop, the Harvard International Law-International Relations Workshop, the Tufts International Law-International Relations Seminar, the Texas Law School faculty workshop, and the Vanderbilt Roundtable on the Law and Politics of International Cooperation. Gilda Anahi Gutierrez, Elena Herrero-Beaumont, Karla Quintana-Osuna, and Rebecca Stubbs provided superb research assistance.

${ }^{1}$ Andean Subregional Integration Agreement, May 26, 1969, 8 ILM 910 (1969) [hereinafter Cartagena Agreement].

${ }^{2}$ The composition of the Andean integration project has shifted over time. The five founding members of the Andean Pact in 1969 were Bolivia, Chile, Colombia, Ecuador, and Peru. Venezuela joined the group as a sixth member in 1973. Chile withdrew in 1976 after the coup by Augusto Pinochet. In 2006 President Hugo Chávez withdrew Venezuela from the Andean Community, and Chile rejoined it as an associate member.

${ }^{3}$ See, e.g., Walter MatTli, The LOGiC Of Regional InTEGration 12, 42 (1999) (characterizing the Andean Pact as one of several "integration schemes [that] have failed at the implementation stage" because their "stated integration goals and subsequent achievements were far apart"); KATRIN NYMAN METCALF \& IOANNIS E. PApageorgiou, Regional InTEgration AND COURTS OF Justice 21-23 (2005) (discounting the achievements of the Andean Community and emphasizing its "perpetual internal crisis," including recent political schisms involving Venezuela and Bolivia); Nora Anton, Bolívar's Dream Come True? Regional Integration and Development in the Andean Community 1-2 (Master Thesis, European Studies, University of Münster, 2006) (stating that "most political and academic discourse on the Andean Community agrees [that the] integration process has, up to now, not been very 'successful', and quite often it is called a complete failure").

However, in several recent works Latin American legal scholars and attorneys analyze the Andean Community's legal structure and the activities of the Andean Tribunal of Justice. See, e.g., JORGE ANTONIO QUINDIMIL LOPEZ, INSTITUCIONES Y DERECHO DE LA COMUNIDAD ANDINA (2006); MARCEL TANGARIFE TORRES, DERECHO DE LA INTEGRACIÓN EN LA COMUNIDAD ANDINA (2002); Mauricio Baquero-Herrera, The Andean Community:
} 
Yet the Andean Community has achieved remarkable success within one part of its legal system. It is not widely known that the Community's judicial arm, the Andean Tribunal of Justice (ATJ or Tribunal), is the world's third most active international court, having issued over fourteen hundred rulings to date. ${ }^{4}$ The ATJ is less active than the European Court of Human Rights and the European Court of Justice, but busier than the more intensively studied International Court of Justice, the institutions of the World Trade Organization (WTO) dispute settlement system, and other international courts and tribunals. ${ }^{5}$ Although activity is not the same thing as effectiveness, the ATJ's caseload suggests that the Andean legal system provides a tool for litigants to protect their rights and interests-particularly for disputes relating to intellectual property (IP) — a subject that dominates more than 90 percent of the ATJ's docket.

Within this single issue-area, the ATJ is both active and effective. ${ }^{6}$ Its rulings have helped to establish intellectual property as a rule-of-law island in the Andean Community and to ensure that legal rules_-rather than power, political influence, or bribery-shape decision making by state actors. ${ }^{7}$ Within the IP rule-of-law island, national judges, administrative officials, and private parties participate in ATJ litigation and conform their behavior to Andean IP rules. In the vast seas surrounding this island, however, Andean rules remain riddled with exceptions, underenforced, and often circumvented by domestic actors.

Our larger theoretical interest lies in identifying how international institutions, including international tribunals, can help to build an effective rule of law. The ATJ's success in building an effective Andean legal system — albeit only within a limited policy space-is all the more remarkable given the weakness of national legal systems in the states subject to the Tribunal's jurisdiction. When we began our research, we had low expectations of the ATJ. Not only have Andean countries faced decades of economic and political instability, they have never had

Finding Her Feet Within Changing and Challenging Multidimensional Conditions, 10 LAW \& BUS. REV. AM. 577 (2004); César Montaño Galarza, Constitución ecuatoriana e integración andina: La situación del poder tributario del Estado, in 2004-I ANUARIO DE DERECHO CONSTITUCIONAL LATINOAMERICANO 949 [hereinafter ANUARIO]; Ricardo Vigil Toledo, La consulta prejudicial en el Tribunal de justicia de la Comunidad andina, 2004-I ANUARIO, supra, at 939; Jorge Luis Suárez Mejías, Integración y supracionalidad en la Comunidad andina proceso decisorio, sistema jurisdiccional y relación con los derechos nacionales ( $\mathrm{PhD}$ thesis, Universidad complutense de Madrid, 2006).

${ }^{4}$ The full texts of judgments of the ATJ are available, in Spanish only, on the Web site of the Andean Community. Procesos del Tribunal de justicia andino, at < http://www.comunidadandina.org/ $>$ (follow "Documentos Oficiales" hyperlink; then follow "Procesos del Tribunal de Justicia” hyperlink).

5 The two most active international courts in terms of number of cases decided are, first, the European Court of Human Rights and, second, the European Court of Justice (ECJ) and its Court of First Instance. See Karen J. Alter, Private Litigants and the New International Courts, 39 COMP. POL. STUD. 22, 26-27 (2006).

${ }^{6}$ We define effectiveness as the degree to which international rules or tribunal rulings produce "observable, desired changes in behavior." Kal Raustiala, Compliance \& Effectiveness in International Regulatory Cooperation, 32 CASE W. RES. J. INT'L L. 387, 394 (2000) (citing numerous international relations scholars who define effectiveness in these terms).

${ }^{7}$ We follow a narrow, formal definition of "rule of law" that requires "the government [to] be ruled by the law and subject to it." JOSEPH RAZ, The Rule of Law and Its Virtue, in THE AUTHORITY OF LAW 210, 212 (1979). This definition stresses the "certainty and predictability of governmental action . . . [and the] actual equality of legal treatment" in "relations between citizens[,] and between citizens and their government." Robert S. Summers, $A$ Formal Theory of the Rule of Law, 6 RATIO JURIS 127, 131, 129 (1993). The antithesis of the rule of law, according to this definition, exists where public officials or economic or political elites employ extralegal channels of influence-including bribery and corruption - to achieve preferred outcomes or policies. See Bruce Ackerman, The New Separation of Powers, 113 HARV. L. REV. 633, 694 (2000) ("A failure to control [corruption] undermines the very legitimacy of democratic government. If payoffs are a routine part of life, ordinary people will despair of the very idea that they, together with their fellow citizens, can control their destinies through the democratic rule of law."). 
strong domestic rules of law or national judiciaries. ${ }^{8}$ The reality that the ATJ is effective, but only within a single issue-area, makes the Andean experience of broader theoretical interest. How did a region with weak legal institutions develop a stable rule of law for IP rights? Why have Andean judges and officials been able to induce widespread respect for Andean rules in intellectual property but not in other areas of regional integration? And what does the Andean Community's island of success portend for other international courts and dispute settlement bodies that exercise authority over countries whose legal, political, and economic conditions are roughly comparable to those prevailing in the Andean countries?

To answer these questions, this article develops a broad, yet measurable, conception of an effective rule of law. Our metric has three separate facets. We inquire, first, into the creation and protection of IP rights for private parties under the Andean legal system; second, into whether national actors - in particular administrative agency officials- habitually implement Andean IP rules as interpreted by Andean judges; and third, into whether individual member countries comply with ATJ rulings in the face of contrary pressure by foreign interests (principally the United States and American pharmaceutical companies). We emphasize in each instance the Tribunal's contributions to enhancing these three dimensions of an effective IP rule of law.

Since the ATJ's activities are not yet widely known but are relevant to understanding the efficacy of international adjudication more generally, we first describe the institutional and legal developments that set the stage for an IP rule of law to emerge. We then document litigation trends, case law developments, and changes in administrative agency decision making that reveal the effectiveness of the Andean IP rule of law. Our analysis is based on a rich variety of primary sources, including the first-ever coding of all ATJ preliminary reference rulings through $2007 ;^{9}$ archival research in the offices of the Andean General Secretariat; and interviews with over forty government officials, current and former national court judges, and members of the Andean Tribunal, industry associations, and law firms in the capitals of Colombia, Ecuador, and Peru.

To generalize beyond the Andean case, we next offer an explanation for why the Andean legal system has succeeded with respect to intellectual property but not other areas of regional integration, such as tariffs, customs, and taxes. We offer three arguments for why IP law

${ }^{8}$ See Andrés Solimano, Political Instability, Institutional Quality and Social Conflict in the Andes, in POLITICAL CRISES, SOCIAL CONFLICT AND ECONOMIC DEVELOPMENT: THE POLITICAL ECONOMY OF THE ANDEAN REGION 15, 38 (Andrés Solimano ed., 2005) [hereinafter POLITICAL ECONOMY OF THE ANDEAN REGION] (comprehensively reviewing domestic legal and political institutions and measures of corruption and concluding that the Andean countries are "weak states" in which the "the rule of law is partial and incomplete, and ... respect for civil rights and property rights is limited"). A recent World Bank study found that Andean countries fall in the bottom 25 percent of all states as measured by a comprehensive index of the rule of law. Daniel Kaufmann et al., Governance Matters VI: Aggregate and Individual Governance Indicators, 1996-2006, World Bank Policy Research Working Paper 4280 (July 2007). For more detailed recent analyses, see LINN HAMMERGREN, ENVISIONING REFORM: IMPROVING JUDICIAL PERFORMANCE IN LATIN AMERICA (2007); Jorge L. Esquirol, The Failed Law of Latin America, 56 AM. J. COMP. L. 75 (2008).

${ }^{9}$ Database of ATJ Rulings, 1987-2007 (2008) (on file with authors). The ATJ recently published, on a different Web site from the one containing its judgments cited in note 4 supra, statistics on the number of decisions issued each year. Tribunal de Justicia de la Comunidad Andina, at $<$ http://www.tribunalandino.org.ec/ $>$. These figures indicate that the ATJ issued a slightly higher number of decisions during this twenty-year period. Our database codes those ATJ decisions that are publicly available and can be downloaded from the Andean Community Web site. 
remains an island. First, Andean rules outside of intellectual property are less precise and contain loopholes that limit their enforceability. This legal reality reflects a broader political reality-that Andean governments are only weakly committed to integration because their most important trade relationships are with other countries. Second, the ATJ refuses to interpret Andean rules purposively so as to promote the integration of regional markets. The ATJ's restrictive interpretive approach reduces the incentives for litigants to mobilize to enforce Andean law and limits pressure on governments to build deeper economic relationships. The third and perhaps most important explanation, however, is the absence of compliance constituencies whose professional interests motivate them to see that Andean laws on the books are actually respected.

Finally, we consider the insights that the ATJ's experience brings to the evaluation of competing theories of effective international adjudication. The growing number of international courts and their increasing activity ${ }^{10}$ have attracted the interest of scholars of international law, international relations, and comparative politics, leading to the launch of new empirical projects, a university press series, and a specialized journal. ${ }^{11}$ This intense academic scrutiny has heightened interest in identifying factors that contribute to effective international adjudication. Some studies of international tribunals cite institutional design to explain why certain international judicial bodies succeed and others fail, stressing factors such as judicial independence, compulsory jurisdiction, and direct access to private parties. ${ }^{12}$ Other studies highlight the strategies of international judges and debate whether efficacy correlates with judicial modesty or judicial activism. ${ }^{13}$ Still other approaches emphasize domestic political and legal context, arguing that international tribunals will be more effective in countries with democratic governments, independent judiciaries, and robust civil societies. ${ }^{14}$

${ }^{10}$ See Karen J. Alter, Delegating to International Courts: Self-Binding vs. Other-Binding Delegation, 71 LAW \& CONTEMP. PROBS. 37 (2008); Laurence R. Helfer \& Anne-Marie Slaughter, Why States Create International Tribunals: A Response to Professors Posner and Yoo, 93 CALIF. L. REV. 899, 931 (2005).

${ }^{11}$ Project on International Courts and Tribunals, at $<$ http://www.pict-pcti.org/>; Oxford University Press Series on International Courts and Tribunals, at $<$ http://www.oup.co.uk/law/series/international-courts $>$; THE LAW AND PRACTICE OF INTERNATIONAL COURTS AND TRIBUNALS: A PRACTITIONERS' JOURNAL (2002-).

12 See, e.g., Robert O. Keohane, Andrew Moravcsik, \& Anne-Marie Slaughter, Legalized Dispute Resolution: Interstate and Transnational, 54 INT'L ORG. 457, 458-60 (2000) (analyzing effectiveness of international tribunals as a function of three variables - independence, access, and embeddedness). For a recent debate over the relationship between independence and efficacy, compare Helfer \& Slaughter, supra note 10, at 931-42 (explaining why states delegate authority to independent international tribunals), with Eric A. Posner \& John C. Yoo, Judicial Independence in International Tribunals, 93 CALIF. L. REV. 1, 8, 27 (2005) (arguing that the only effective international tribunals are "dependent" tribunals, meaning tribunals staffed by judges closely controlled by governments through the power of reappointment or threats of retaliation).

${ }_{13}$ See Laurence R. Helfer \& Anne-Marie Slaughter, Toward a Theory of Effective Supranational Adjudication, 107 YALE L.J. 273, 308 (1997) (describing how European courts strategically "manipulate[d] factors within their control to maximize their impact on the relevant national actors"). For recent analyses of whether international courts should engage in judicial activism, see Lorand Bartels, The Separation of Powers in the WTO: How to Avoid Judicial Activism, 53 INT'L \& COMP. L.Q. 861 (2004); James L. Cavallaro \& Stephanie Erin Brewer, Reevaluating Regional Human Rights Litigation in the Twenty-first Century: The Case of the Inter-American Court, 102 AJIL 768 (2008); Vaughan Lowe, Advocating Judicial Activism: The ITLOS Opinions of Judge Ivan Shearer, 2005 AUSTL. Y.B. INT'L L. 145, 151-52.

${ }^{14}$ See, e.g., Keohane, Moravcsik, \& Slaughter, supra note 12, at 478 (positing that liberal democracies will be more receptive to efforts to "embed international law in domestic legal systems"); Anne-Marie Slaughter, $A$ Liberal Theory of International Law, 94 ASIL PROC. 240, 241-45 (2000) (arguing that domestic regime type in general and liberal democracy in particular are important factors for explaining compliance with international commitments). 
Our study of the Andean legal system offers new evidence to assess these competing theories. The Andean case is especially interesting because the ATJ is a replica of the European Court of Justice (ECJ), widely regarded as the gold standard of effective international tribunals. The ATJ copies the ECJ's key design features, including a preliminary ruling mechanism, a noncompliance procedure, and the foundational doctrines of supremacy and direct effect of Community rules over conflicting national laws. ${ }^{15}$ The legal, political, and economic conditions in the Andes, however, are very different from those in Europe. The ATJ experience thus serves as a natural experiment to evaluate alternative theories predicting when international tribunals succeed or fail and how they can help to construct and bolster an effective rule of law.

The Andean experience also introduces another previously unexplored phenomenon- that islands of effective international adjudication can arise even when the surrounding domestic and international laws and institutions remain weak or inactive. ${ }^{16}$ The notion that international tribunals can contribute to building an effective rule of law in some areas within their jurisdiction while failing to do so in others assumes greater importance when multilateral cooperation falters. ${ }^{17}$ In such an environment, one way forward may be to build regional or subregional rule-of-law islands, and later extend those islands to larger issue-specific or geographically bounded archipelagoes in which international and domestic legal rules are widely respected. ${ }^{18}$

The institutional architecture for such a development already exists. For example, many regional trade agreements have set up judicial or quasi-judicial institutions designed to promote adherence to legal rules. Since 1990, eight international courts have been established by regional treaties that cover trade and economic issues. ${ }^{19}$ Analogous trends are occurring in other issue-areas. Three international and several hybrid tribunals have been created to address atrocities in specific countries, ${ }^{20}$ and regional human rights courts and commissions in Europe,

${ }^{15}$ See, e.g., Helfer \& Slaughter, supra note 13; Eric Stein, Lawyers, Judges, and the Making of a Transnational Constitution, 75 AJIL 1 (1981); J. H. H. Weiler, The Transformation of Europe, 100 YALE L.J. 2403 (1991).

${ }^{16}$ Cf. GABRIELLA BLUM, ISLANDS OF AGREEMENT: MANAGING ENDURING ARMED RIVALRIES (2007) (analyzing why islands of successful cooperation sometimes persist in interstate relationships principally characterized by armed conflicts).

17 The collapse of the Doha Round of trade talks at the World Trade Organization provides a recent and salient example. See Daniel Pruzin \& Eric J. Lyman, Doha Talks Collapse over U.S.-India Dispute on Ag Safeguards; Future of Round in Doubt, WTO Rep. (BNA) (July 30, 2008).

${ }^{18}$ For a discussion of how to promote international cooperation over time by expanding subject matter or membership rules, see Kenneth W. Abbott \& Duncan Snidal, Pathways to International Cooperation, in THE IMPACT OF INTERNATIONAL LAW ON INTERNATIONAL COOPERATION: THEORETICAL PERSPECTIVES 50 (Eyal Benvenisti \& Moshe Hirsch eds., 2004).

19 The eight regional courts and the dates of their establishment are the Court of Justice of the African Union (2003), the Caribbean Court of Justice (2002), the Court of Justice for the Common Market of Eastern and Southern Africa (1993), the Common Court of Justice and Arbitration of the Organization for the Harmonization of Corporate Law in Africa (1993), the Economic Court of the Commonwealth of Independent States (1993), the European Free Trade Area Court (1992), the Central American Court of Justice (1991), and the Court of Justice for the Arab Maghreb Union (1999). Project on International Courts and Tribunals, at <http://www.pict-pcti. org/>; see also < http://www.aict-ctia.org $>$. Other important regional trade and economic agreements, including NAFTA, MERCOSUR, and the ASEAN-China Free Trade Area, establish quasi-judicial or arbitral dispute settlement mechanisms.

${ }^{20}$ The four war crimes courts are the International Criminal Tribunal for the Former Yugoslavia (1993), the International Criminal Tribunal for Rwanda (1994), the International Criminal Court (1998), and the International Criminal Tribunal for Sierra Leone (2003). Hybrid tribunals were established in response to atrocities in Sierra Leone, Kosovo, East Timor, and Cambodia. See Project on International Courts and Tribunals, supra note 19. 
the Americas, and Africa have become increasingly active over the last decade. ${ }^{21}$ Many of these bodies exercise jurisdiction over countries with weak domestic legal systems. Understanding how the Andean Tribunal of Justice has helped to build an island of effective international adjudication in a region where democratic regimes are not fully entrenched, the rule of law is fragile and often ignored, and domestic courts are not fully independent may provide an important exemplar for other international courts and dispute settlement bodies.

The remainder of this article proceeds as follows. Part I describes the founding of the Andean integration project, the subsequent changes in both the ATJ's jurisdiction and Andean IP rules, and the creation of domestic IP administrative agencies. Part II analyzes each of the three facets of an IP rule of law. Part III considers why the Andean legal system is effective in intellectual property but not in other areas of regional integration. Part IV analyzes the insights of the Andean experience in relation to broader theoretical debates about the efficacy of international courts and tribunals, in particular those with jurisdiction over countries outside Europe. Part $\mathrm{V}$, a brief conclusion, assesses the ATJ's future prospects.

\section{THE LEGAL AND INSTITUTIONAL FRAMEWORK OF THE ANDEAN COMMUNITY}

\section{The Rise and Fall of the Andean Pact and the Birth of the Andean Tribunal}

In 1969 the five nations of the Andes region ${ }^{22}$ established a regional integration agreement modeled on the European Community (EC). The Andean Pact's founding treaty, the Cartagena Agreement, ${ }^{23}$ established a supranational governance structure that included a "Commission" of national executives, who adopted Andean legislation (known as "Decisions"), and a regional administrative body (the "Junta") that supervised the implementation of those Decisions. ${ }^{24}$ It did not, however, establish an international court to interpret Andean legal rules or review complaints alleging noncompliance with those rules.

Although the Andean Pact copied the European Community's legislative and executive architecture, the substantive policies of the two regions were quite different. Whereas the European integration project focused on liberalizing trade and creating a common market, the Andean Pact's raison d'être was import substitution-promoting regional development as an alternative to purchasing goods and technologies from foreign firms. The Andean Commission sought to achieve this goal by heavily regulating foreign investment, subsidizing domestic industries, and distributing jobs, factories, and infrastructure projects according to the needs of each member country. ${ }^{25}$

Although the Andean Pact's distinctive policy orientation attracted a flurry of attention in the 1970s, its implementation soon faltered. Member states counted on an influx of foreign capital to fund regional economic development. But few businesses were willing to invest in

${ }^{21}$ See, e.g., Alter, supra note 5, at 57-58.

22 See supra note 2.

${ }^{23}$ Cartagena Agreement, supra note 1.

${ }^{24}$ For more on the Andean Pact, see ThOmas ANDREW O'KeEFE, LATIN AMERICAN TRADE AgreEMENTS 1, 1-5 to 1-7 (1997); Salgado Germánico Peña Herrera, Viable Integration and the Economic Co-operation Problems of the Developing World, 19 J. COMMON MKT. STUD. 175 (1980); Miguel S. Wionczek, The Rise and the Decline of Latin American Economic Integration, 9 J. COMMON MKT. STUD. 49, 59-61 (1970).

${ }^{25}$ See Scott Horton, Peru and Ancom: A Study in the Disintegration of a Common Market, 17 TEX. J. INT'L L. 39, 49 (1982). 
remote areas lacking in infrastructure and political stability only to be subjected to heavyhanded regulation. ${ }^{26}$ In addition, frequent changes of government and economic instability made domestic officials reluctant to follow Andean policies. ${ }^{27}$

The member states responded by creating a judicial mechanism to enforce Andean rules. In 1979, once again copying Europe, they adopted a treaty to establish the Andean Tribunal of Justice (ATJ Treaty) ${ }^{28}$ and endowed it with powers mirroring those of the ECJ: (1) a noncompliance mechanism empowering the Junta to challenge a state's failure to comply with Andean law; (2) a nullification procedure to contest supranational decisions as ultra vires; and (3) a preliminary reference procedure for national courts to submit questions of Andean law to the ATJ as they arose during domestic litigation. As in the European Community, lower courts were permitted to make references to the Tribunal and courts of last instance were required to do so. ${ }^{29}$

The Andean Pact's continuing problems also hobbled the new judicial system when it began operating in 1984. During the Tribunal's first decade, the funds that member states had pledged to the ATJ were delayed and it received little substantive work. National courts filed only thirty-two preliminary reference requests, private parties filed only three nullification complaints, and the Junta refrained from filing any noncompliance suits. ${ }^{30}$ All told, it was not an auspicious beginning for the ATJ, yet hardly surprising given the political and economic divisions plaguing the Andean Pact.

By the late 1980s, a pervasive debt crisis in Latin America had pushed the Andean Pact to the brink of failure. Using the substantial economic leverage that crisis engendered, the World Bank, the Inter-American Development Bank, and the International Monetary Fund (IMF) pressed Andean governments to adopt a broad array of liberalizing and deregulatory reforms. These reforms, known as the "Washington Consensus," 31 engendered fundamental changes in how Andean countries regulated their economies. National governments—acting on their

${ }^{26}$ David E. Hojman, The Andean Pact: Failure of a Model of Integration? 20 J. COMMON MKT. STUD. 139 (1981); see also Albert Berry \& Francisco Thoumi, Import Substitution and Beyond, 5 WORLD DEV. 89 (1977); Rosemary Thorp, The Post-Import-Substitution Era: The Case of Peru, 5 WORLD DEV. 125 (1977).

${ }^{27}$ In 1970, for example, the member states agreed to internal free trade for products that no country had a stake in protecting. A common external tariff was projected to be in place by 1980 , but member countries continued to disagree about the tariff throughout the 1980s and early 1990s. See William P. Avery \& James D. Cochraine, Innovation in Latin American Regionalism: The Andean Common Market, 27 INT'L ORG. 181, 191-92 (1973); Hojman, supra note 26, at 140, 147-51, 156-59; Osvaldo Saldías, Supranational Courts as Engines of Disintegration: The Case of the Andrean Community 23-25 (Free Univ. of Berlin Working Paper on European Integration No. 5, 2007), available at <http://www.fu-berlin.de/polsoz/polwiss/europa/arbeitspapiere/2007-5_Saldias.pdf $>$.

${ }^{28}$ Treaty Creating the Andean Tribunal of Justice, May 28, 1979, 18 ILM 1203 (1979) [hereinafter ATJ Treaty]. The Tribunal, which has its headquarters in Quito, Ecuador, is composed of one judge for each member nation of the Andean Community. Judges must be nationals of a member state and of high moral character, and either fulfill the conditions for exercising the highest judicial office in their countries of origin or be jurisconsults of recognized competence. Each judge is appointed by a unanimous decision of the member states from a slate of three candidates submitted by each country. Judges are "fully independent" and serve for a six-year term that may be renewed once. Id., Arts. 7-9. For additional information on the ATJ and its operations, see Ricardo Vigil Toledo, Dispute Settlement in Andean Community Law, in INTER-GOVERnMENTAL TRADE DiSPUTE SETTLEMENT: MULTILATERAL AND REGIONAL APPROACHES 245 (Julio Lacarte \& Jaime Granados eds., 2004).

${ }^{29}$ ATJ Treaty, supra note 28, Arts. 17-31; E. Barlow Keener, The Andean Common Market Court of Justice: Its Purpose, Structure, and Future, 2 EMORY J. INT'L DISP. RESOL. 39, 49-58 (1987).

${ }^{30}$ Database of ATJ Rulings, supra note 9 . The Tribunal dismissed the only noncompliance case, filed by a private litigant in 1987, on standing grounds. Case 1-AI-87, 1-INCUMP-87 (Oct. 22, 1987) (Aluminio Reynolds).

31 See John Williamson, What Washington Means by Policy Reform, in LATIN AMERICAN ADJUSTMENT: HOW MuCH HAS HAPPENED? 7, 7-20 (John Williamson ed., 1990). 
own and through Andean institutions_-adopted major policy reforms to achieve open, market-based economies and created new institutions staffed by Western-educated professionals who endorsed these goals. A complete account of the Washington Consensus and the waves of reform it spawned is beyond the scope of this article. ${ }^{32}$ Here, we focus on those reforms that contributed to building a rule-of-law island for intellectual property. We begin by describing how the reforms acted as a catalyst for member states to overhaul Andean institutions and rewrite regional legislation, including Andean IP rules.

\section{Restructuring Andean Institutions and Expanding the ATJ's Jurisdiction}

In response to the demands of international financial institutions and growing domestic dissatisfaction with the slow pace of regional economic growth, national governments relaunched Andean integration in the mid-1990s. They amended the Cartagena Agreement, jettisoned the import-substitution policy, replaced it with a free trade model based on a common market, and rechristened the new integration system as the Andean Community. ${ }^{33}$

Major institutional changes accompanied this evulsive policy shift. Member states replaced the ineffectual Junta with a General Secretariat, increased the size of its budget, and appointed a new cadre of young lawyers eager to use the secretariat's enhanced resources to promote regional integration. ${ }^{34}$ The member states also expanded the ATJ's authority. First, they authorized private actors to challenge member states' noncompliance with Andean laws by filing complaints with the General Secretariat, subject to a right of appeal to the ATJ ${ }^{35}$ Second, they indicated that ATJ judges could address how Andean rules applied to the facts of cases referred by national courts pursuant to the preliminary-ruling mechanism. ${ }^{36}$

These reforms, which were part of a wider effort to increase public access to Andean institutions, ${ }^{37}$ made it more difficult for member states to block the enforcement of Andean laws. The General Secretariat could now credibly argue that its own failure to initiate a noncompliance suit would prompt private actors to file their own noncompliance actions. These institutional changes were thus prerequisites for the activation of the Andean legal system. Equally important, however, were the revision of the region's IP rules and the creation of new domestic IP administrative agencies.

\footnotetext{
32 For a comprehensive analysis, see YVES DEZALAY \& BRYANT G. GARTH, GLOBAL PRESCRIPTIONS: THE Production, EXPORTATION, AND IMPORTATION OF A NEW LEGAL ORTHODOXY (2002).

${ }^{3}$ See Thomas Andrew O'Keefe, How the Andean Pact Transformed Itself into a Friend of Foreign Enterprise, 30 INT'L LAW. 811, 818 (1996) (describing how Andean governments "reformulate[d] . . the entire philosophical underpinnings of the Andean Pact" and promoted "the adoption of free market-oriented economic policies by all the member states").

${ }^{34}$ Interviews with Monica Rosell, former legal secretary of the ATJ and attorney in the Legal Advisor's Office of the Secretariat General, Quito, Ecuador (Mar. 17, 2005), \& Chicago, Ill. (Apr. 1, 2007).

35 Treaty Creating the Court of Justice of the Cartagena Agreement, Art. 25, as amended by Protocol of Cochabamba (May 28, 1996), available at <http://www.comunidadandina.org/ingles/normativa/ande_trie2.htm > [hereinafter Revised ATJ Treaty].

${ }^{36}$ Id., Art. 34 (amending ATJ Treaty to authorize the ATJ to "refer to th[e] facts [in dispute] when essential for the requested interpretation"). The Cochabamba Protocol also authorizes the ATJ to hear three other types of cases: complaints against a Community body that "abstain[s] from carrying out an activity for which it is expressly responsible," arbitrations, and Community labor disputes. Id., Arts. 37-40. The ATJ has rarely exercised these functions.

37 This effort included publication of reports by the General Secretariat describing its efforts to promote Andean integration and the creation of an Andean Community Web site. Interviews with Rosell, supra note 34.
} 
TABLE 1.

SUMMARY OF ANDEAN INTELLECTUAL PROPERTY DECISIONS 1974-PRESENT

\begin{tabular}{|c|c|c|}
\hline Decision No. & Overview of Content & Dates in Effect \\
\hline Decision 24 & $\begin{array}{l}\text { Placing extensive regulation and licensing restrictions on IP } \\
\text { protection for foreign investors }\end{array}$ & 1970-1991 \\
\hline Decision 85 & Granting minimal protection to trademarks and patents & 1974-1991 \\
\hline Decision 291 & $\begin{array}{l}\text { Reducing regulation and licensing restrictions on intellectual } \\
\text { property of foreign investors }\end{array}$ & 1991-present \\
\hline Decision 311 & $\begin{array}{l}\text { Modestly expanding trademark and patent protection } \\
\text { (including of some pharmaceuticals) }\end{array}$ & 1991-1992 \\
\hline Decision 313 & $\begin{array}{l}\text { Conferring same protection as Decision 311, with shorter } \\
\text { phase-in periods }\end{array}$ & 1992-1994 \\
\hline Decision 344 & $\begin{array}{l}\text { Making IP rules mostly consistent with multilateral } \\
\text { standards in WTO/TRIPS Agreement }\end{array}$ & 1994-2000 \\
\hline Decision 486 & $\begin{array}{l}\text { Having similar effect as Decision 344, with more detailed } \\
\text { procedures and enforcement mechanisms }\end{array}$ & 2000-present \\
\hline Decision 632 & Interpreting data protection provision of Decision 486 & 2005-present \\
\hline Decision 689 & $\begin{array}{l}\text { Adjusting ten specific patent and trademark provisions of } \\
\text { Decision } 486\end{array}$ & 2008-present \\
\hline
\end{tabular}

\section{The Evolution of Andean Intellectual Property Rules}

Regulation of intellectual property has been an important part of Andean integration since the Andean Pact's founding. The Cartagena Agreement itself proclaims the need for "a common system for treatment of . . trademarks, patents, licenses, and royalties." 38 To achieve this goal, national executives, acting as members of the Andean Commission, have adopted numerous regional laws, or "Decisions," to regulate these subjects. ${ }^{39}$ The Decisions, summarized in table 1 above, have direct effect in national legal systems. ${ }^{40}$ They are also precise and detailed, as befits regulations "intended to serve, not as broad-brush treaty norms, but as the domestic law of each of the five [member] countries." ${ }^{1} 1$

As the summary of Decisions in the table indicates, Andean IP rules have changed radically over the forty-year life of the Community. The earliest Decisions subordinated the property rights of investors to the region's economic development goals, treating patents and trademarks

${ }^{38}$ Cartagena Agreement, supra note 1, Art. 27 (now Art. 55).

39 The Decisions on these subjects referred to in this article are described in table 1 . The Andean Community has also adopted common regional legislation concerning other intellectual property issues, including copyright and neighboring rights (Decision 351 of 1993), the rights of breeders of new plant varieties (Decision 345 of 1993), and access to genetic resources (Decision 391 of 1996). All Andean Decisions are available in Spanish on the Andean Community Web site, <http://www.comunidadandina.org/>.

${ }^{40}$ Decision 85 gave Andean countries six months to implement its provisions. Later Decisions came into force when published in the Official Gazette and had direct effect as of that date. See Case 26-IP-2002, at 13 (May 2, 2002) (interpreting Dec. 344).

${ }^{41}$ Robert M. SHERWOOd \& CARlos Alberto Primo BragA, INTElleCtUAL Property, Trade AND ECONOMIC DEVELOPMENT: A ROAD MAP FOR THE FTAA NEGOTIATIONS 14 (1996), available at $<$ ns.kreative.net/ipbenefits/download/roadmap.rtf $>$. As interpreted by the ATJ, Andean IP Decisions permit member states to adopt national IP rules, but only if such rules are consonant with regional standards. See, e.g., Case 2-IP-88, at 3-4 (May 30, 1988) (interpreting Dec. 85) (adopting the principle of "indispensable complement" pursuant to which member states are limited to enacting "complementary measures that are strictly necessary for the implementation of the Community [IP] norm, . . that favor the application of the Community norm and by no means obstruct or nullify it"). 
as vehicles for transferring technology from foreign firms. ${ }^{42}$ In the early 1990 s, member states shifted course and adopted four Decisions that mandated progressively higher levels of IP protection. These new regional laws reflected the market liberalization goals of the later phases of the Washington Consensus. ${ }^{43}$ But other factors reinforced the impetus for change: the inclusion of IP rules in the Uruguay Round of multilateral trade negotiations and threats of trade sanctions by the United States.

Colombia and Peru - the two Andean countries that were members of the General Agreement on Tariffs and Trade-recognized that the soon-to-be-established World Trade Organization would include a treaty on intellectual property rights. Andean states opposed strong IP protection. But they realized that the Agreement on Trade-Related Aspects of Intellectual Property Rights (TRIPS) would be the price of admission to the new global trading system. ${ }^{44}$ TRIPS was attractive for other reasons. First, it offered a way to end the threat of U.S. trade sanctions. By adapting regional rules to emerging multilateral standards, Andean governments hoped to end the U.S. Trade Representative's practice of placing them on "priority watch lists" for refusing to recognize the IP rights demanded by foreign businesses. ${ }^{45}$ Adopting these standards would also alleviate pressure by the World Intellectual Property Organization (WIPO), whose officials had long attempted to persuade Andean governments to follow the multilateral IP rules that TRIPS later incorporated. ${ }^{46}$

Yet even as member states agreed to TRIPS, they retained an awareness from the Andean Pact's import-substitution days that IP regulation could be tailored to achieve other economic and social objectives important to developing countries. For example, early Andean patent rules did not protect pharmaceuticals. Later Decisions did so, but with important exceptions that restricted the IP rights of foreign drug companies. These exceptions nurtured a thriving regional generics industry that produced low-cost medicines. ${ }^{47}$ Analogous provisions had been included in the region's trademark laws. For example, Andean legislation required all trademark owners to use their trademarked goods and services in Andean commerce or risk losing them to local competitors.

As of 1994, although Andean IP rules were consistent with TRIPS, they fell short of the demands of U.S. IP rights holders for more capacious IP protection. The United States and its

${ }^{4}$ See Frederick M. Abbott, Bargaining Power and Strategy in the Foreign Investment Process: A Current Andean Code Analysis, 3 SYRACUSE J. INT'L L. \& COM. 319, 349-50 (1975).

${ }^{43}$ See Inter-Am. Dev. Bank, Office of Evaluation and Oversight, Evaluation of MIF Projects: Market Functioning: Promotion of Competition and Consumer Protection, MIF/GN-78-14 (2003) (discussing "second generation" Washington Consensus reforms that emphasized the governments' provision of public goods and services, including intellectual property).

${ }^{44}$ Laurence R. Helfer, Regime Shifting: The TRIPS Agreement and New Dynamics of International Intellectual Property Lawmaking, 29 YALE J. INT'L L. 1, 18-24 (2004). For the TRIPS Agreement, see Agreement on Trade-Related Aspects of Intellectual Property Rights, Marrakesh Agreement Establishing the World Trade Organization, Annex 1C, Apr. 15, 1994, in World Trade Organization, The LEgal TEXTS: The Results OF THE URUGUAY ROUND OF TRADE NEGOTIATIONS 321 (1999) [hereinafter TRIPS Agreement].

45 SUSAN K. SELL, POWER AND IDEAS: NORTH-SOUTH POLITICS OF INTELLECTUAL PROPERTY AND ANTITRUST 113-40 (1998).

46 See Roberto Salazar Manrique, The Andean Community's Intellectual Property Regime, in THE ANDEAN COMMUNITY AND THE UNITED STATES: TRADE AND INVESTMENT RELATIONS IN THE 1990S at 212, 218 (Miguel Rodriguez et al. eds., 1998); Interview with Alfonso Vidales Olviedo, former head of the Secretariat General Office of the Legal Adviser and chief negotiator of Decision 85, Lima, Peru (June 22, 2007).

${ }^{47}$ Manrique, supra note 46, at 216-17. 
IP industries responded by pressuring individual Andean countries to negotiate bilateral treaties and to enact domestic laws containing enhanced IP rules. These strategies caused some national executives to defect from Andean rules, but, as we explain below, the ATJ and the General Secretariat proved to be hospitable forums for the region's generic drug industry to challenge these defections as violations of Andean law. However, compliance with the ATJ rulings upholding these challenges would not have occurred without the support of domestic IP agencies, whose restructuring was also a product of the Washington Consensus reforms.

\section{Restructuring Domestic IP Administrative Agencies}

The international financial institutions that promoted liberalization of Andean markets did not expect that the adoption of market-friendly policies would on their own generate significant economic growth. Part of the Washington Consensus, therefore, included a call for new legal and regulatory institutions to facilitate the working of national markets. To meet this objective, the multilateral development banks and the IMF supported a second wave of reforms in which governments would restructure and strengthen the administrative agencies that regulated the market in areas such as consumer protection, competition, bankruptcy, transparency, and intellectual property. ${ }^{48}$

These pressures dovetailed with ongoing efforts of Andean governments to reform the domestic administrative state. ${ }^{49}$ In 1992 Peru established the National Institute for the Defense of Competition and the Protection of Intellectual Property (INDECOPI), an agency that cobbled together subjects, including intellectual property, consumer protection, and bankruptcy, that had previously been unregulated or scattered across several ministries. ${ }^{50}$ In that same year, the Colombian government established a Superintendent of Industry and Commerce (SIC) and entrusted the office with a similar array of competences. ${ }^{51}$ Other Andean countries also created or restructured their domestic IP agencies over the next several years. ${ }^{52}$

\footnotetext{
${ }^{48}$ This focus on agency regulation of newly liberalized markets is often referred to as the "second generation" of Washington Consensus reforms. See Inter-Am. Dev. Bank, supra note 43.

49 The literature on this point is vast. For a recent survey, see Fabrizio Gilardi, Jacint Jordana, \& David Levi-Faur, Regulation in the Age of Globalization: The Diffusion of Regulatory Agencies Across Europe and Latin America 15 (IBEI [Institut Barcelona d'estudis internacionals] Working Paper No. 2006/1), available at <http://papers.ssrn.com/ sol3/papers.cfm?abstract_id $=960739>$.

50 On the origins of INDECOPI, see Michael P. Ryan, Intellectual Property Institutions and the Public Administration of Knowledge in Developing Countries: The Case of Indecopi in Peru, in THE ROLES OF THE STATE IN COMPETITION AND INTELLECTUAL PROPERTY POLICY IN LATIN AMERICA: TOWARDS AN ACADEMIC AUDIT OF INDECOPI 319 (Beatriz Boza ed., 2000); David G. Becker, Justice for Peruvian Consumers? INDECOPI and Consumer Protection (Sept. 2001) (Paper presented at the 23d Int'l Congress of the Latin American Studies Ass'n) (on file with authors).

${ }^{51}$ See Colombia Ministry of Commerce, Industry and Tourism, Superintendencia de Industria y Comercio, at $<$ http://www.sic.co/> [hereinafter SIC].

52 Bolivia created the National Intellectual Property Service (SENAPI) in 1996; Venezuela created a similar agency, the Servicio autónomo de la propiedad intelectual (SAPI), one year later; and in 1998 Ecuador established the "Ecuadorian Institute of Intellectual Property (EIIP), a public juridical entity with its own assets and administrative, economic, financial and operative autonomy." Cecilia Falconi Perez, Ecuador: New Intellectual Property Law (Oct. 28, 1998), at<http://www.grain.org/bio-ipr/?id=91>; see also U.S. DEP'T OF STATE, OFFICE OF THE COORDINATOR FOR BUSINESS AFFAIRS, BOLIVIA COUNTRY COMMERCIAL GUIDE (1996); Telephone interview with Ricardo Colmenter, former legal counsel for the SAPI (Mar. 19, 2007).
} 
INDECOPI, SIC, and the other IP agencies in the region were logical recipients of aid from the international financial institutions. The institutions helped the agencies to improve their efficiency and transparency, providing funds and technical assistance to modernize their operations, train personnel, and adopt new technologies to disseminate information. This externally funded support helped to transform the agencies into relatively well-resourced institutions able to carry out their mandates free from domestic political pressures. It particularly benefited agencies like INDECOPI, whose budget is funded mainly by fines and IP registration fees rather than by public tax revenues, and whose organization as a public corporation "exempts it from civil service personnel rules" and "insulates it from the day-to-day managerial control of the executive branch." 53 The agencies' autonomy also attracted Western-educated officials and staff who strongly supported economic liberalization and the rule of law. Some of these professionals made their careers advancing in the agencies' ranks. ${ }^{54}$

Among the many functions that the new agencies performed was the review of applications to register patents, trademarks, and other IP rights. Administrators applied Andean IP Decisions to determine whether to grant or reject these applications, in the process identifying gaps and ambiguities in the Decisions. Since all of the agencies applied the same regional rules, their lawyers and engineers naturally sought the advice of their peers in other member states. These consultations engendered an informal regional network of IP agency officials and staff who shared information, developed criteria to resolve common legal problems, and came to view themselves as engaged in highly skilled and technical activities. ${ }^{55}$ Several of the new agencies were also tasked with protecting consumers, a mandate that informed their views as to the proper balance between private rights and the public interest. ${ }^{56}$

The Andean General Secretariat supported this nascent regional network. ${ }^{57}$ It also consulted the IP agencies during the revisions of Andean IP Decisions in the late 1990s. The next iteration of Andean IP rules (Decision 486, adopted in 2000) drew on the agencies' expertise to close lacunae and clarify ambiguities while maintaining many distinctive features of Andean IP

${ }^{53}$ Becker, supra note 50, at 9 (characterizing INDECOPI as having "some of the autonomy possessed by independent U.S. governmental agencies such as the Federal Trade Commission”); see also Manuel Ruiz, Sociedad peruana de derecho ambiental, IP-Related Technical Co-operation, Assistance and Capacity Building: The Peruvian Experience (July 2005) (ICTSD Dialogue on Technical Cooperation for IP Policy in Developing Countries, Geneva) ("INDECOPI is ... perceived by the Peruvian public (in many public polls) as an institution which maintains its institutional autonomy and is thus not affected by political pressure").

${ }^{54}$ In Peru, for example, President Fujimori appointed Beatriz Boza, "a distinguished associate of a New York law firm and the respected chair of the Committee on Inter-American Affairs of the Association of the Bar of the City of New York, to the presidency of INDECOPI's Board of Directors." Boza, in turn, recruited a staff of young, proreform economists and lawyers, many with foreign training or work experience. Becker, supra note 50, at 10. For a more detailed analysis of similar trends throughout Latin America, see YVES DEZALAY \& BRYANT G. GARTH, THE INTERNATIONALIZATION OF PALACE WARS: LAWYERS, ECONOMISTS, AND THE CONTEST TO TRANSFORM LATIN AMERICAN STATES 176-80 (2002); JORGE I. DOMÍNGUEZ, TECHNOPOLS: FREEING POLITICS AND MARKETS IN LATIN AMERICA IN THE 1990S (1997).

${ }^{55}$ Interviews with officials of INDECOPI, Lima, Peru ( June 21, 2007). Meetings funded by WIPO encouraged the formation of these networks. See Ruiz, supra note 53 (stating that "co-operation between the Andean Community, WIPO and national IP authorities has been constant over the years").

${ }^{56}$ As we explain below, the IP agencies' consumer protection mandate contributed to the consumer protection concerns that have been a prominent feature of ATJ jurisprudence. See infra text at notes 119-20.

${ }^{57}$ Article 121 of Decision 313 provided a mandate "to strengthen, foster the autonomy of and modernize the competent national [IP] offices, and the information systems and services in accordance with the latest technology." Common Code on Intellectual Property, Dec. 313 (1992), reprinted in 32 ILM 182 (1993). 
law. ${ }^{58}$ These consultations gave agency officials a voice in Andean rule making and, as a result, a stake in implementing those rules. ${ }^{59}$

In sum, the emergence of domestic administrative agencies with a professional interest in enforcing Andean rules was an important catalyst for the development of a rule-of-law island for intellectual property. As we explain below, the agencies' registration of trademarks and patents generated a demand by private actors for Andean litigation that enabled the ATJ to clarify the content of regional IP rules and to resolve disputes on the basis of those rules.

\section{Activating the Andean Tribunal of Justice}

As the IP agencies began to issue more trademark and patent registration decisions, ${ }^{60}$ appeals to national courts to challenge those decisions also increased. Yet businesses and their counsel had little faith that national judges, most of whom have no training in IP law, could master the specialized and technical issues it often involves. They thus preferred to have the ATJ interpret the Andean IP rules rather than leave it to national courts to review the agencies' decisions on their own. ${ }^{61}$

Our coding of ATJ case law reflects this increasing demand for Andean litigation. Consider first the number of decisions. Between its first decision in 1985 and the end of 2007, the ATJ issued 1338 decisions in response to requests from national courts for preliminary rulings interpreting Andean laws. ${ }^{62}$ As noted above, the number of such rulings during the Tribunal's first decade from 1985 to 1994 totaled only 32. As figure 1 (p. 14) indicates, the number of decisions began to rise sharply beginning in the mid-1990s, a period that followed the restructuring of the IP administrative agencies. ${ }^{63}$ The annual output peaked in 2006, when the ATJ issued 228 judgments. In 2007 the number of judgments declined to 175, higher than all but the previous two years.

The rising number of preliminary rulings over time suggests that the ATJ is following the trajectory of the ECJ, whose docket is dominated by such rulings. ${ }^{64}$ But this similarity to

${ }^{58}$ Interviews with Rosell, supra note 34.

59 Various scholars have found that engaging the actors charged with implementing an agreement increases support for and compliance with international rules. See, e.g., RACHEL CICHOWSKI, THE EUROPEAN COURT AND CiVIL SOCIETY: LiTIGATION, MOBILIZATION AND GOVERNANCE 13-21 (2007); Harold K. Jacobson \& Edith Brown Weiss, Assessing the Record and Designing Strategies to Engage Countries, in ENGAGING COUNTRIES: STRENGTHENING COMPLIANCE WITH INTERNATIONAL ENVIRONMENTAL ACCORDS 511 (Harold K. Jacobson \& Edith Brown Weiss eds., 1998).

${ }^{60}$ We document the rising number of applications to register trademarks and patents in the first section of part II infra.

${ }^{61}$ E.g., Interview with José Barreda, Barreda Moller law firm, Lima, Peru (June 18, 2007); Interview with Carlos Olarte, partner, Olarte Raisbeck \& Frieri Ltda, Bogotá, Colombia (Sept. 10, 2007); Interview with Marcel Tangerife, Tangarife Torres \& Associates, Lima (Sept. 10, 2007).

${ }^{62}$ Database of ATJ Rulings, supra note 9. This figure contrasts with the much smaller number of noncompliance rulings (70) and nullification rulings (28) during the same period, revealing that preliminary rulings constitute approximately 93 percent of all ATJ decisions. Id. Scholars and attorneys in the Andean region have noted the importance of ATJ preliminary rulings. See, e.g., Alejandro Daniel Perotti, Algunas consideraciones sobre la interpretación prejudicial obligatoria en el derecho andino, GACETA JURÍDICA DE LA COMUNIDAD EUROPEA (ser. D) No. 213, May/June 2001, at 90; Vigil Toledo, supra note 3, at 942.

${ }^{63}$ Data for figure 1 were taken from Database of ATJ Rulings, supra note 9.

${ }^{64}$ Clifford J. Carrubba \& Lacey Murrah, Legal Integration and Use of the Preliminary Ruling Process in the European Union, 59 INT'L ORG. 399 (2005). 
Figure 1. Number of ATJ Preliminary Rulings, 1987-2007

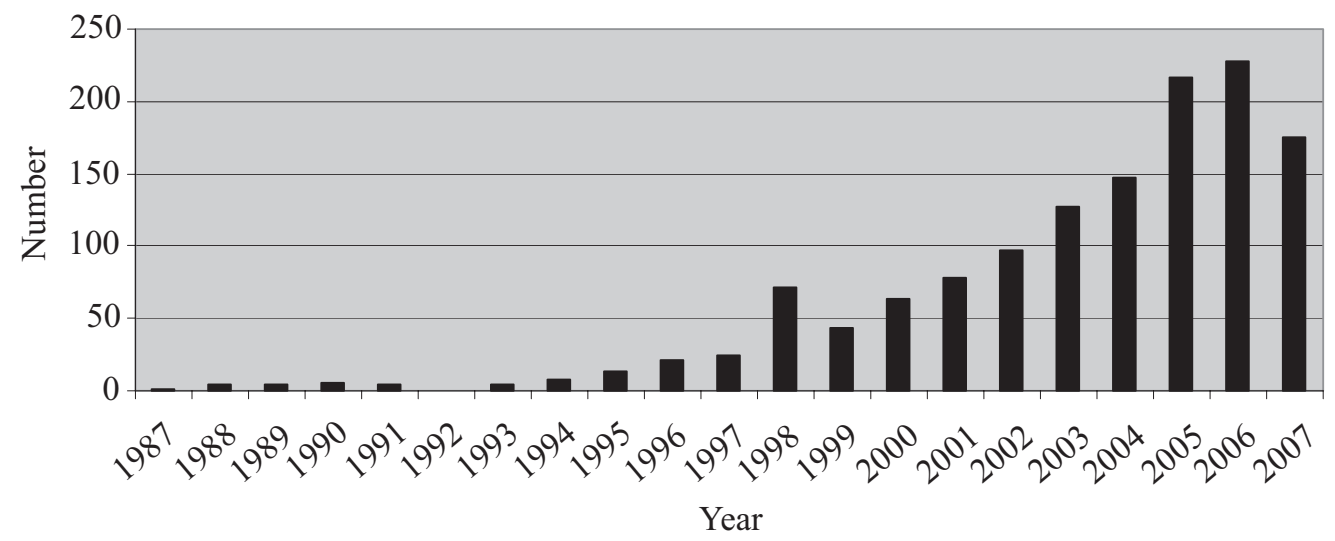

European litigation is only superficial. ECJ preliminary rulings canvass the full range of issueareas regulated by EC law. ${ }^{65}$ In contrast, references from national courts in the Andean Community are overwhelmingly dominated by intellectual property issues. Of the 1338 ATJ preliminary rulings issued through the end of 2007, 1303 (97 percent) concern IP: 1165 (87 percent) interpret Andean trademark legislation; 103 (8 percent) involve Andean patent rules; 11 (less than 1 percent) deal with copyrights; and 24 (less than 2 percent) concern other IP types, such as industrial designs and utility models. ${ }^{66}$ Only 35 of the 1338 preliminary rulings (2.5 percent) concern issues other than IP.

The domestic origin of these 1338 preliminary rulings is also remarkably uniform-1285 cases began as challenges to an agency's decision to grant or deny an application to register a trademark, patent, or other intellectual property right. This striking statistic reveals that IP agency registration decisions were responsible for nearly 96 percent of the ATJ preliminary references.

The relatively constant rate of increase in Andean rulings and their homogeneous subject matter could be seen as a reflection of a steadily growing awareness among national judges of their place within the Andean legal system — if only for appeals from administrative agency decisions involving intellectual property. Nevertheless, our coding of the national origin of ATJ referrals and our interviews with domestic judges belie this conclusion.

In the early years of the ATJ's existence, national courts of last instance ignored their obligations under the ATJ Treaty and did not refer questions of Andean law to the Tribunal. In response, IP attorneys personally lobbied judges, and, where that failed, filed noncompliance actions with the Andean General Secretariat challenging the refusal to refer cases. National judges had no experience in referring cases to international courts, and they were concerned that doing so would involve a loss of sovereignty. However, once judges were made aware of their obligations and realized that referring cases to the ATJ would not significantly undermine

${ }^{65}$ Alec Stone Sweet, The Judicial Construction of Europe 72 (2004).

${ }^{66}$ One IP-related issue is strikingly absent from these statistics — disputes relating to Andean Community Decision 391 (1996), which regulates access to genetic resources. Monica Rosell, Access to Genetic Resources: A Critical Approach to Decision 391 'Common Regime on Access to Genetic Resources' of the Cartagena Agreement, 6 REV. EUR. CMTY. \& INT’L ENVTL. L. 274 (1997). 
Figure 2. ATJ PRELIMINARY RULings, 1987-2007, By COUNTRY AND YeAR

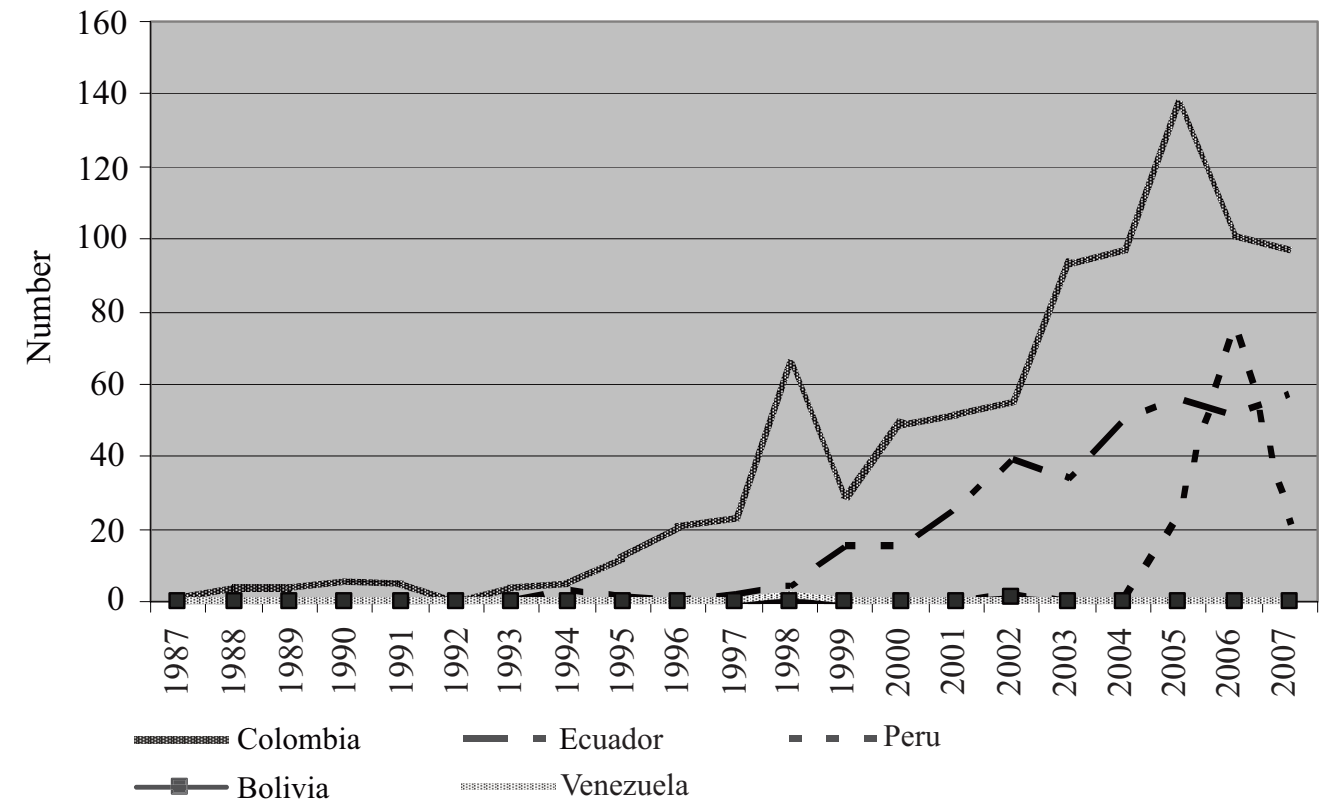

their decision-making power, they started referring a large number of IP cases to the Tribunal. ${ }^{67}$ For intellectual property, overcoming national judicial skepticism was akin to uncorking a tap. Beginning in the mid-1990s, each uncorking produced a sharp increase in the ATJ's docket, as figure 2 reveals.

Figure 2 also reveals cross-national variation regarding when national courts overcame their reluctance to refer cases, and in the number of references. ${ }^{68}$ Colombia was the first country to refer a case, in 1987, and it is responsible for nearly two-thirds of all preliminary ruling requests. ${ }^{69}$ Ecuadoran courts submitted their first referral in 1994, after informal lobbying by

${ }^{67}$ Interview with Judges Marco Antonio Velilla Moreno, Martha Sofía San Tobón, Dr. Rafael E. Ostau de Lafont Pianeta, and Camilo Arciniegas Andrade, Council of State of Colombia, First Section, Bogotá (Sept. 12, 2007) [hereinafter Interview with judges of the Council of State]; Interview with Judge Elcira Vásquez Cortez, then head of the Judicial Control Office and member of the Constitutional and Social Chamber of the Supreme Court of Justice of Peru, Lima (June 21, 2007); Interview with Judges Eloy Torres Guzmán, president of the court and of Chamber 1, and Ernesto Muñoz Borrero, president of Chamber 2, Administrative Tribunal for District No. 1, Quito, Ecuador (Mar. 15, 2005).

${ }^{68}$ Data for figure 2 were taken from Database of ATJ Rulings, supra note 9. We discuss the patterns of national court references to the ATJ in greater detail in another paper. Laurence R. Helfer \& Karen J. Alter, Building Judicial Supranationalism in the Andes: Understanding Preliminary Reference Patterns in the Andean Community, 41 N.Y.U. J. INT'L L. \& POL. (forthcoming 2009).

${ }^{69}$ Differences in national judicial structure partly explain why Colombia is the source of most ATJ referrals. In contrast to other member states, in Colombia IP agency registration decisions are appealable to the First Section of the Council of State, a first and last instance administrative court separate from the remainder of the judicial system. The members of the Council come from a variety of backgrounds and are appointed for an eight-year nonrenewable term, after which they return to their former careers. Our interviews disclosed that Council members do not vie for judicial promotions, nor are they committed to protecting domestic judicial power. Interview with judges of the Council of State, supra note 67. They have thus been amenable to the court-to-court collaborations that ATJ preliminary references require. 
ATJ judges ${ }^{70}$ and a General Secretariat decree holding Ecuador in violation of Andean law because it had failed to refer cases. ${ }^{71}$ The Peruvian Supreme Court began to make referrals in 2005, after two noncompliance decrees against Peru $^{72}$ and a meeting between Peruvian judges, government officials, and General Secretariat lawyers. ${ }^{73}$ In contrast, Bolivia and Venezuela have together referred only three cases. ${ }^{74}$

In part III, we explain the absence of referrals from Bolivian and Venezuelan judges and argue that the lack of cases from these countries reflects an outer boundary of the region's IP rule-of-law island. But other than these two instances, the fact- and context-specific explanations for cross-national variations are not especially revealing of how the island arose or how it functions.

Far more important is the subject matter skewing of preliminary rulings. Andean Community legislation spans a broad range of subjects, including customs, taxes, tariffs and nontariff barriers to trade, competition, and insurance. Under the ATJ Treaty, lower national courts may, and national courts of last instance must, refer questions of Andean law to the Tribunal. This provision applies to cases in which the parties themselves have raised issues of Andean law, as well as those in which Andean rules are relevant to their dispute. ${ }^{75}$ Our interviews suggest that national judges refer all appeals of IP agency decisions to the Tribunal, but that they do not see the need to refer cases involving domestic legislation that implements or contradicts Andean law. Since all Andean Decisions have direct domestic effect and prevail in cases of conflict with national law, ${ }^{76}$ a variety of legal issues should be available for preliminary reference. In part III, we attempt to unravel the mystery of the Tribunal's lopsided docket. Before doing so, we explain how the Andean legal system helped to build the rule of law in the area of intellectual property.

\section{Constructing AN EFFECTIVE IP RULE OF LAW IN THE ANDEAN COMMUNiTY}

Many legal scholars evaluate whether or not a legal system is effective by considering the extent of compliance with its rules. ${ }^{77}$ International relations theorists determine effectiveness

\footnotetext{
${ }^{70}$ Interview with Judges Torres Guzmán and Muñoz Borrero, supra note 66; Interview with Judge Galo Pico Mantilla of the ATJ, 1987-1993, Quito (Mar. 17, 2005).

${ }^{71}$ General Secretariat [GS] Res. 171, Infringement Decree No. 51-98 (Dec. 17, 1998) (Ecuador); GS Res. 210 (Mar. 31, 1999) (Ecuador) (responding to a motion to reconsider Res. 171).

${ }^{72}$ GS Res. 459, Infringement Decree No. 38-2000 (Dec. 5, 2000) (Peru); GS Res. 771, Infringement Decree No. 173-2003 (Sept. 22, 2003) (Peru).

${ }^{73}$ El principio de cooperación judicial entre el Tribunal andino y los tribunales nacionales en el marco de la Comunidad andina (Nov. 28, 2003), available at <http://www.cajpe.org.pe/RIJ/Memorias/principio1.htm>; Interview with Judge Vásquez Cortez, supra note 66.

${ }^{74}$ Database of ATJ Rulings, supra note 9.

75 Revised ATJ Treaty, supra note 35, Art. 33 (stating that the obligation of national judges to refer cases applies to cases in which an Andean rule "is litigated" as well as disputes in which Andean rules "should be applied").

${ }^{76}$ The ATJ announced the doctrines of direct effect and supremacy of Andean Community law in its earliest rulings - citing landmark ECJ judgments. See, e.g., Cases 1-IP-87 (Dec. 3, 1987), \& 2-IP-88, supra note 41 (both interpreting Dec. 85, see table 1, p. 9 supra). The member states later incorporated the direct effect principle into Andean Decisions. See Case 26-IP-2002, supra note 40, at 13.

77 See, e.g., Richard H. McAdams, The Expressive Power of Adjudication, 2005 U. ILL. L. REV. 1043, 1045-49 (2005); Posner \& Yoo, supra note 12, at 28. Noncompliance may indicate that a regime is ineffective, but compliance in itself does not mean that an international rule or institution is effective. See George Downs et al., Is the Good News About Compliance Good News About Cooperation? 50 INT’L ORG. 379 (1996).
} 
Figure 3. Total Patent Applications by Country and Year

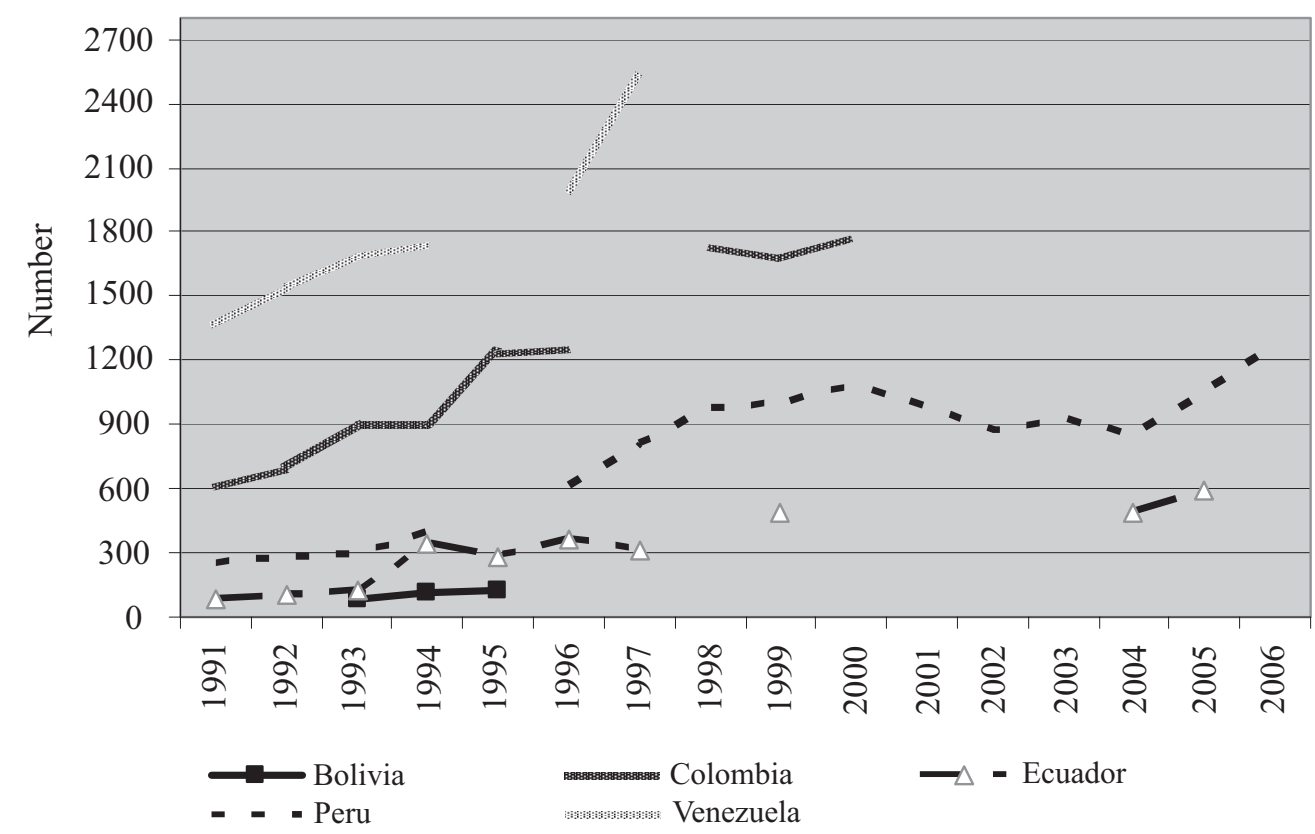

by assessing whether states behave differently than they otherwise would have done because international rules or institutions exist. ${ }^{78}$ We incorporate both of these assessments into our analysis of how the ATJ helped to construct and bolster the rule of law in the Andean Community. But we also consider elements that are taken for granted in well-functioning legal systems-whether decisions by state actors are made pursuant to legal rules rather than power, political influence, or bribery.

Our analysis proceeds in three parts. First, we ask whether Andean IP rules influence the expectations and behavior of private actors. We document a growing demand for trademarks and patents, an increase in disputes over IP ownership, and the rise of a specialized bar devoted to the registration and enforcement of intellectual property rights. These trends reveal that businesses and their counsel are voting with their feet; rights holders file and defend applications for trademarks and patents because IP rights have economic value and because agency proceedings and litigation can effectively secure that value.

Second, we ask whether ATJ litigation has contributed to the reasoned, evenhanded, and transparent application of Andean rules by domestic IP agencies and shaped substantive doctrines. We evaluate the ATJ's case law and, drawing on interviews with lawyers and agency officials, demonstrate that the ATJ has created the kind of legal procedures and standards that one would expect in well-functioning legal systems.

Third, we investigate compliance with ATJ rulings, focusing on how the ATJ and the General Secretariat induced governments to reverse policies that violated Andean IP rules. The cases we discuss show how the ATJ helped to rebuff pressure by the United States and multinational corporations to circumvent Andean IP rules, leading to different behavior by national actors from what it would have been in the absence of the Andean legal system.

\footnotetext{
${ }^{78}$ See, e.g., STEPHEN KRASNER, INTERNATIONAL REgimes 5-10 (1983); Raustiala, supra note 6, at 388.
} 
Figure 4. Total Trademark Applications by COUNTRY AND Year

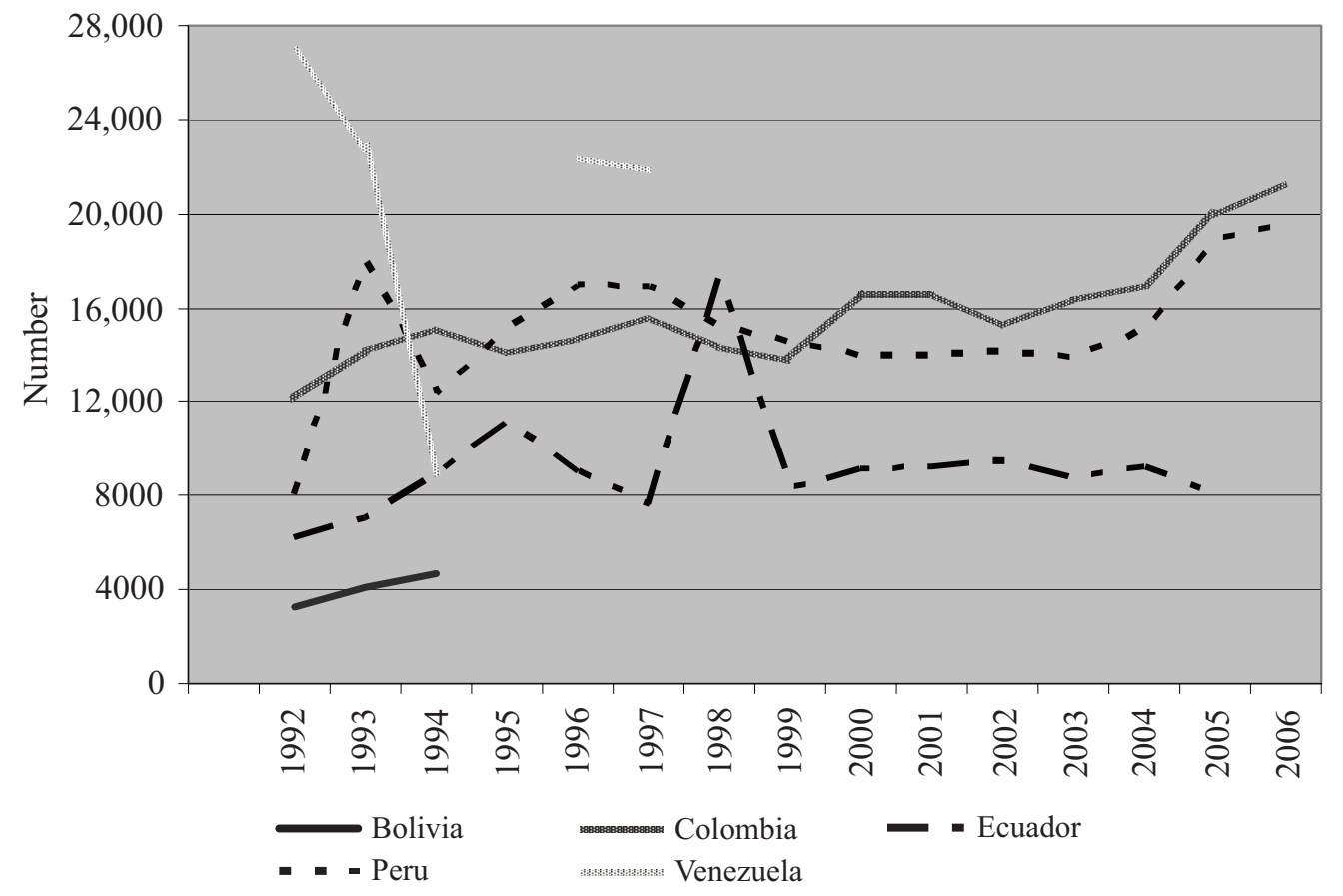

\section{The Rising Demand for and Economic Value of Andean IP Rights}

At the most basic level, an effective rule of law creates rights protected by enforceable legal rules that apply equally to similarly situated actors. Several indicators reveal that Andean IP rights meet this standard. Statistics gathered from domestic IP agencies and interviews with attorneys indicate that trademarks and patents are economically valuable and that the procedures governing their acquisition and adjudication are effective.

Figures 3 (p. 17) and 4 exhibit a growing demand for trademark and patent protection in the Andean Community. Applications for patents and trademarks rose immediately after the restructuring of domestic IP administrative agencies and the revision of Andean IP Decisions in the early and mid-1990s. ${ }^{79}$

In Colombia, for example, patent applications increased nearly threefold between 1991 and 2000 (the last year for which data are available), and trademark applications rose more than 76 percent between 1992 and 2006. Data from the IP agencies also record the nationality of the applicants for IP rights. In the case of patents, foreign firms were responsible for between 85 and 95 percent of all filings. Between 50 and 60 percent of trademark applications, however, emanated from domestic businesses. ${ }^{80}$

\footnotetext{
${ }^{79}$ Data for figures 3 and 4 were provided by WIPO, Statistics Data and Indicators, at <http://www.wipo.int/ ipstats/en/statistics/>. In figures 3 and 4, trademark and patent application data for Peru from 1998 to 2006 were provided by INDECOPI; and trademark application data for Colombia were provided by SIC. No data were available for some countries in some years.

${ }^{80}$ Patent and trademark applications filed by individuals or businesses in other Andean countries are counted as nonresident applications.
} 
Figure 5. Number of ATJ Preliminary Rulings InVOlVing OpPositions to APPLiCATIONS TO REGISTER A TRADEMARK OR PATENT

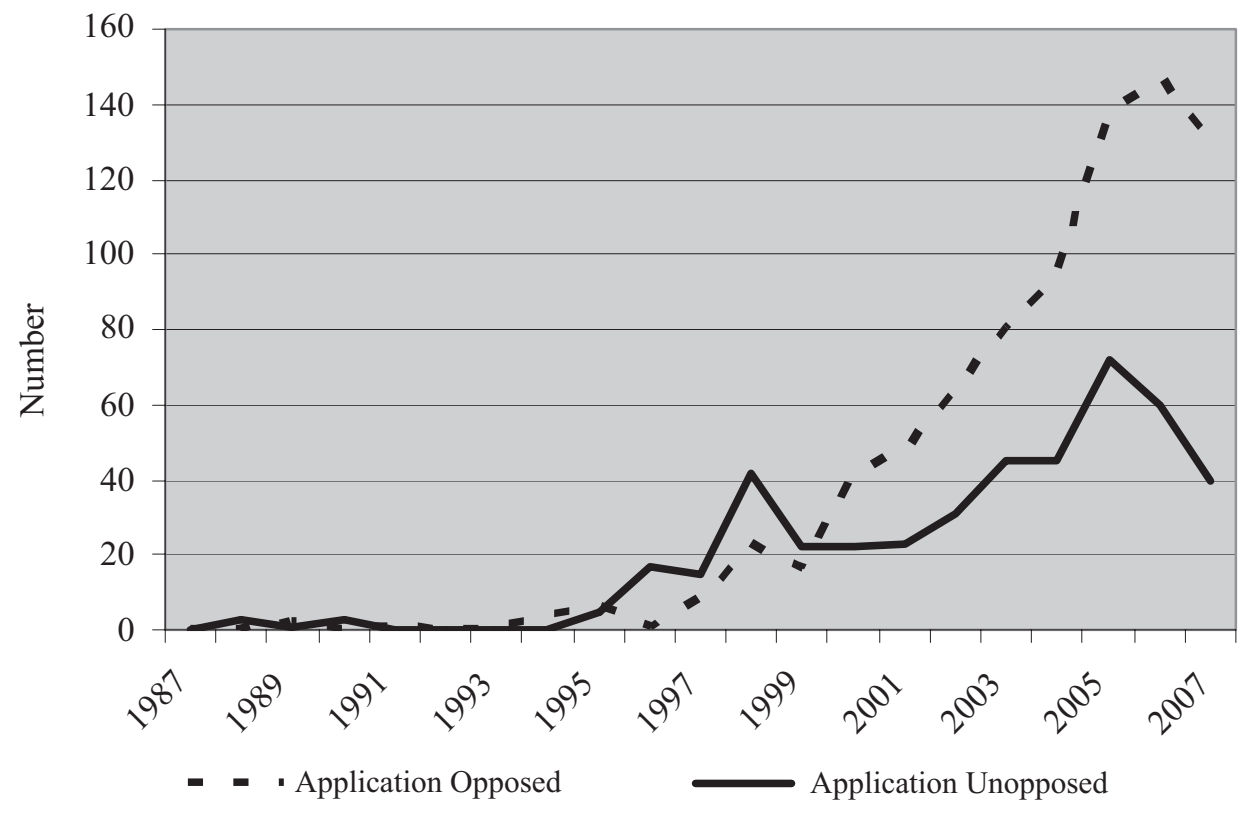

Another indicator of the growing regional interest in intellectual property is the number of private parties that oppose applications to register trademarks and patents. Oppositions are usually filed by business competitors that own trademarks or patents similar to those that applicants seek to register, or by firms, such as generic drug producers, that benefit from the lack of IP protection in a particular industry. ${ }^{81}$ That these businesses take the time and expense to oppose IP applications is one indication of the economic value of registering a trademark or patent.

The available evidence suggests that IP oppositions have increased markedly over the past decade. Figure 5 shows the number of disputes involving IP registrations that reached the ATJ through preliminary references. ${ }^{82}$ In the early and mid-1990s, most patent and trademark applications were uncontested. Over the next decade, however, private parties lodged a substantially larger number of oppositions to IP applications at the administrative level. By the middle of the next decade, cases involving oppositions outnumbered uncontested cases by a ratio of greater than two to one.

Officials in the patent and trademark divisions of INDECOPI and SIC confirmed that the number of oppositions has been rising over the last decade, a trend that they attributed to the growth of IP industries and IP-related investment in the region and the wider societal recognition of the economic value of patents and trademarks. ${ }^{83}$ Many IP holders are also repeat

${ }^{81}$ See 3 MCCARTHY ON TRADEMARKS AND UNFAIR COMPETITION $\$ 20: 2$ (4th ed. 2007) (describing trademark opposition procedures); Mark D. Janis, Rethinking Reexamination: Toward a Viable Administrative Revocation System for U.S. Patent Law, 11 HARV. J.L. \& TECH. 1, 28, 93-117 (1997) (reviewing patent and trademark opposition rules in several national jurisdictions).

${ }^{82}$ Data for figure 5 were taken from Database of ATJ Rulings, supra note 9.

${ }^{83}$ Interview with Giancarlo Marcenaro Jiménez, head of Industrial Property Division, SIC, Bogotá (Sept. 12, 2007); Interview with Nestor Escobedo, head of INDECOPI Patent Office, Lima (June 21, 2007). 
players in the Andean legal system, suggesting that they have found the system to be an effective way to protect their rights. ${ }^{84}$

The growing demand for IP rights has also fueled an expansion of legal specialists in the region. For example, a lawyer in Ecuador estimated that there used to be ten lawyers or firms in the country whose practices included IP issues, but by 2004 approximately two hundred single lawyers or firms were practicing in the area. ${ }^{85}$ In Peru, a leading IP lawyer told us that his firm had added IP law to its corporate law practice in 1997. In 2007 the firm decided to focus exclusively on intellectual property, while the corporate lawyers split off to form their own practice. ${ }^{86} \mathrm{~A}$ Colombian lawyer estimated that twenty law firms in Bogotá now specialize in intellectual property, whereas there were perhaps five firms ten years ago. ${ }^{87}$

For most areas of Andean law, neither litigation nor jurisprudence is reported in scholarly publications. Intellectual property is a striking exception. Many IP law firms publish newsletters in which they review recent developments and tout the firms' accomplishments, seeking to attract new clients in an increasingly competitive market for legal services. ${ }^{88}$ By 2004 , interest in intellectual property among the region's legal community was strong enough to merit the creation of a new specialized journal- the Anuario andino de derechos intelectuales. ${ }^{89}$ These developments suggest that the audience for information about Andean IP law has achieved a critical mass.

Interviews provided additional evidence that statistics alone cannot show. We asked every attorney with whom we spoke whether the empirical picture described above reflected reality-that is, whether applications for and oppositions to IP rights were increasing, whether agency and judicial decision making reflected rules on the books, and whether attorneys could protect the trademarks and patents registered by their clients. The answer was a uniform yes, regardless of whether the attorney worked for the government, an industry association, a local family-owned law firm, or a branch of a global law firm with multinational corporate clients. ${ }^{90}$

This answer is itself remarkable. The attorneys we interviewed were pessimistic about the Andean Community as a whole. They repeatedly stated that for many subjects the region's legal system did not work, that rules were drafted to allow for domestic derogations, and that ATJ

${ }^{84}$ To take just three salient examples: the U.S. shipping giant UPS, the European food conglomerate Nestlé, and the Colombian food producer Alpina each participated in more than ten agency registration proceedings—as both applicants and opponents - as well as national court appeals and ATJ preliminary rulings to protect their respective trade and service marks in the region. See, e.g., Case 223-IP-2005 (Feb. 2, 2006) (interpreting Dec. 344) (UPS); Case 146-IP-2005 (Sept. 20, 2005) (interpreting Dec. 486) (Nestlé); Case 238-IP-2005 (Mar. 24, 2006) (interpreting Dec. 344) (Alpina); see also Database of ATJ Rulings, supra note 9.

${ }^{85}$ Interview with Dr. Gustavo Romero and Carolina Guerrero, Firma Romero Arteta Ponce, Quito (Mar. 16, 2005) [hereinafter Interview with Firma Romero Arteta Ponce].

${ }^{86}$ Interview with Barreda, supra note 61.

${ }^{87}$ Interview with Juan Pablo Bonilla, Estudio Ernesto Rengifo, Bogotá (Sept. 13, 2007).

88 See, e.g., LATIN AM. InTEll. Prop. Newsl. (Baker \& McKenzie), Mar. 2004; InTEll. Prop. Update (Olarte Raisbeck \& Frieri Ltda), Sept. 2007; Interview with Barreda, supra note 61; see generally NEWSLETTER (Barreda Moller law firm), at < http://www.barredamoller.com/english/bm_publica.asp $>$.

${ }^{89}$ For the Anuario's Web site, see <http://www.anuarioandino.com/index.htm $>$.

${ }^{90}$ See, e.g., Interview with Barreda, supra note 61; Interview with Alvaro Correa, Ricardo Metke, Georgette Otero, and Mauricio Bello, Raisbeck, Lara, Rodríguez \& Rueda (a member of Baker \& McKenzie International) (Sept. 11, 2007); Interview with Escobedo, supra note 83; Interview with Marcenaro Jiménez, supra note 83; Interview with Teresa Mera Gómez, member of INDECOPI Tribunal, Lima (June 21, 2007); Interview with Olarte, supra note 61; Interview with Tangerife, supra note 61. 
and General Secretariat decisions often enabled governments to do as they pleased. ${ }^{11}$ Yet the attorneys largely took for granted that the Andean IP system functions effectively as a rule of law should - through the habitual application of legal rules and procedures.

The domestic IP agencies received much of the credit for this result. Attorneys interviewed in 2005 and 2007 commented favorably on the quality of agency officials' legal and technical analysis. This was not always the case. Prior to the creation of the domestic IP agencies in the 1990s, commentators alleged that IP disputes were often resolved through political connections, "back channels," and even bribery. ${ }^{92}$ Our interviews with agency officials and the private actors who are their clients strongly suggest that the use of these extralegal means diminished with the creation of independent and professionalized administrative agencies.

\section{Bolstering the Rule of Law in Domestic Administrative Agencies}

Our coding reveals that the ATJ's case law is highly repetitive. Appeals from administrative agencies often raise the same legal issues, such as whether two trademarks for similar products are likely to cause confusion, whether a trademark is famous, and whether an invention satisfies the requirements for patentability. ${ }^{93}$ National judges, in turn, repeatedly ask the ATJ to interpret the same provisions of Andean law even when the Tribunal has already plainly stated its interpretation of those provisions. ${ }^{94}$ The ATJ responds to these requests in kind, regurgitating its analysis and sometimes cutting and pasting paragraphs from its earlier rulings. ${ }^{95}$

This repetition is a source of frustration for the Andean intellectual property bar. Attorneys complain that many ATJ rulings are "elementary and repetitive; substantively there is little new" because the Tribunal rarely indicates how Andean rules, as it has interpreted them, should be applied to the facts of the case. ${ }^{96}$

But repetition also serves a different function - it helps to overcome domestic judicial resistance. Our coding and interviews revealed that national judges were reluctant to cede authority

${ }^{91}$ For representative examples, see infra part III.

92 See, e.g., EDGARDO BUSCAGLIA \& CLARISA LONG, U.S. FOREIGN POLICY AND INTELLECTUAL PROPERTY RightS IN LATIN AMERICA 28 (Hoover Essays in Public Policy, 1997) (asserting that "[i]nterest groups representing pirate industries are currently buying the votes of members of Latin American legislatures where the enactment of patent laws seems more likely"); Becker, supra note 50, at 27 (asserting that, prior to the creation of INDECOPI, disputes involving major foreign investors would have been resolved through "back channels").

93 See, e.g., Case 90-IP-2004, at 3, 5, 6-8 (Aug. 25, 2004) (interpreting Dec. 344) (Procter \& Gamble) (likelihood of confusion); Case 162-IP-2004, at 7, 11 (Jan. 26, 2005) (interpreting Dec. 344) (Nestlé) (famous trademarks); Case 49-IP-2005, at 5 (Apr. 14, 2005) (interpreting Dec. 344) (Gillette) (patentability).

${ }^{4}$ The ATJ does not follow acte claire, an ECJ doctrine that directs national judges to refrain from referring copycat cases and instead to apply earlier ECJ rulings. See Case 283/81, Srl CILFIT v. Ministry of Health, 1982 ECR 3415, 3430. Two recent articles have considered whether Andean judges should follow the ECJ's example. See Patricio Bueno Martínez \& Alejandro Daniel Perotti, La teoría del acto aclarado. ¿Resulta necesaria su aplicación en el marco de la interpretación prejudicial andina? DíKAION, Nov. 2005, at 133 (Universidad de La Sabana, Colom.); Perotti, supra note 63, at 4-6. A 2006 ATJ ruling instructing the Colombian Council of State to "look at precedent" in previous cases involving pharmaceutical trademarks suggests that the Tribunal may be ready to do so. Case 164IP-2006, at 12 (Mar. 6, 2007) (interpreting Dec. 486) (directing the Council of State to apply ATJ decisions in Cases 172-IP-2005 (Nov. 25, 2005) (interpreting Dec. 344) and 34-IP-2006 (Apr. 31, 2006) (interpreting Dec. 486) (Merck)).

${ }^{9}$ See, e.g., Case 4-IP-2001 (May 2, 2001) (interpreting Dec. 344) (Novartis); Case 45-IP-2006 (Apr. 19, 2006) (interpreting Dec. 344) (Warner Lambert).

${ }^{96}$ E.g., Interviews with attorneys in IP law firms in Bogotá and Lima. 
to the ATJ or to provoke political controversy by challenging domestic decrees or laws. ${ }^{97}$ The sameness of preliminary references, and the ATJ's responses to those references, made national judges more accepting of a symbiotic relationship with their Andean counterparts, eventually engendering habituation that made preliminary references in IP cases unremarkable. Once national judges had established a relationship with the ATJ, clear and repetitive rulings helped to expedite the disposition of cases and facilitate compliance. For example, the judges of the Colombian Council of State- the ATJ's first and most frequent domestic judicial interlocutor-explained that they "accept the interpretation" of the ATJ in every referred case, but that "[w] hen the Tribunal is clearer, it makes the application easier and quicker." 98

By far the most favorable assessment of ATJ preliminary rulings, however, came from the lawyers and professional staff of domestic IP agencies — the administrators who interpret and apply Andean law on a daily basis. As a member of the INDECOPI administrative tribunal and former head of the agency's Trademark Office stated:

We [the members of the INDECOPI administrative tribunal] expect and await the [ATJ] rulings. We read the rulings and they help us to clarify the procedures and substantive issues in the law. We apply the rulings as soon as they come down from the tribunal, and we reference the rulings in the texts of our decisions about registrations. ${ }^{99}$

The head of the Industrial Property Division at SIC in Colombia concurred, stating that ATJ "rulings certainly help" the division's work. "We read all the decisions, and discuss the important points," especially now that the Internet makes it possible to "review cases immediately" after the Tribunal decides them. ${ }^{100}$ The IP agency's Compendio de doctrina confirms the influence of Andean jurisprudence in the agency's work. This 2005 publication comprehensively catalogues the procedural rules and substantive standards that SIC applies when reviewing trademark and patent applications. It is peppered with quotes from ATJ preliminary rulings. ${ }^{101}$ While Venezuela was a member of the Andean Community, its Servicio autónomo de la propiedad intelectual (SAPI) followed a similar practice. According to SAPI's former legal counsel, the agency viewed ATJ rulings as persuasive authority and referred to them in hundreds of IP registration decisions. ${ }^{102}$

The generally favorable impression of Andean case law reported by national judges and administrators suggests that the repetitiveness of ATJ judgments has a value that has eluded the private IP bar. Attorneys appear to be frustrated by the Tribunal's repetition precisely because they have internalized the validity of regional IP rules and are seeking more specific guidance from Andean judges. ${ }^{103}$ A decade ago, however, attorneys, national courts, and administrative agencies

\footnotetext{
97 Several attorneys, who requested anonymity, stated that they would not use a preliminary reference to challenge a domestic law as contrary to an Andean Decision or to the Cartagena Agreement. Instead, they would bypass national judges and file a noncompliance action with the General Secretariat and then, if that body rejected the case, with the ATJ. For a more detailed discussion, see Helfer \& Alter, supra note 68.

${ }^{98}$ Interview with judges of the Council of State, supra note 67.

${ }^{99}$ Interview with Mera Gómez, supra note 90.

${ }^{100}$ Interview with Marcenaro Jiménez, supra note 83.

${ }^{101}$ SIC, COMPENDIO DE DOCTRINA: PROPIEDAD INDUSTRIAL (2005) (on file with authors).

${ }^{102}$ Interview with Colmenter, supra note 52.

${ }^{103}$ Cf. Guillermo O'Donnell, On the State, Democratization and Some Conceptual Problems: A Latin American View with Glances at Some Postcommunist Countries, 21 WORLD DEV. 1355, 1357 (1993) (stating that "[t]he effectiveness of the law ... consists of innumerable habituated behaviors that (consciously or not) are usually consistent with the prescriptions of the law").
} 
had not fully accepted the supremacy of Andean law or the ATJ's authority. ${ }^{104}$ Seen from this perspective, a high degree of repetition may be a rational strategy for an international court seeking to inculcate habitual compliance with its rulings in countries where the domestic rule of law is weak.

A deeper analysis of ATJ decisions provides further support for this position. In tracking the evolution of Andean case law in our coding, we identified four trends that suggest that repetition has strengthened adherence to the rule of law in the region's domestic IP agencies.

First, the quality of information in preliminary references has improved markedly over time. Early referrals omitted basic facts and procedural histories. In case after case, the ATJ responded by calling for a complete factual record. ${ }^{105}$ Administrative agencies and national courts reacted, in turn, by furnishing details about the parties, the history of the dispute, and the legal issues at stake. Eventually, the ATJ standardized preliminary reference requests. Colombian and Peruvian judges showed us request forms that require them to provide specific items of information. ${ }^{106}$ This standardization has reduced many basic errors that IP agencies committed in early registration proceedings. ${ }^{107}$ More important, it has facilitated the systematic application of legal rules to similarly situated applicants_ — an essential feature of the rule of law.

Second, the ATJ has adopted procedures to protect private actors that oppose applications to register trademarks and patents. An early and influential decision involved a challenge by an association of generic drug manufacturers to the registration of pipeline patents - an issue we analyze below. The Ecuadoran IP agency rejected the opposition, stating that a presidential decree required that it approve such patents. The ATJ disagreed. It reasoned that "an association of pharmaceutical laboratories has a prima facie legitimate interest in the subject of pharmaceutical patents" that may violate Andean norms. ${ }^{108}$ Over the next several years, the

\footnotetext{
${ }^{104}$ Two examples suffice to illustrate this point. First, in Case 9-IP-99, the ATJ stated that it was "required" to repeat its analysis because the Colombian SIC continued to refer to the Tribunal's preliminary rulings as merely persuasive authority. Case 9-IP-99, at 5 (June 11, 1999) (interpreting Dec. 344) (Procter \& Gamble). The Tribunal quoted its earlier ruling in Case 4-IP-97 (Jan. 20, 1998) (interpreting Dec. 344), where it stated that "it is strange for this Community Tribunal, that after having clarified repeatedly and precisely the nature and reach of the preliminary reference, the national competent office of a country can still consider this only a probatory piece of evidence." Case 9-IP-99, supra, at 5-6. Second, in Case 25-IP-2002, a patent applicant challenged a prior ATJ ruling prohibiting the registration of pipeline patents - a ruling we analyze in part III infra. Case 25-IP-2002, at 2 (May 8, 2002) (interpreting Dec. 344). In direct contravention of this earlier ruling, the applicant argued that the Tribunal had no competence to review the validity of a national law, even one that conflicts with Andean Decisions. The ATJ categorically rejected this claim. Id. at 18-19.

105 These factual omissions exist in decisions spanning the first decade of ATJ rulings. See, e.g., Case 1-IP-87, supra note 76; Case 3-IP-88 (Sept. 9, 1988) (interpreting Dec. 85) (Daimler-Benz); Case 1-IP-91 (Feb. 8, 1991) (interpreting Dec. 85); Case 2-IP-91 (Feb. 26, 1991) (interpreting Dec. 85); Case 4-IP-93 (Sept. 20, 1993) (interpreting Dec. 85); Case 6-IP-93 (Feb. 25, 1994) (interpreting Dec. 85); Case 7-IP-96 (Aug. 29, 1997) (interpreting Dec. 85 \& Dec. 344). For an example of an ATJ request for additional factual information and information regarding national laws, see, for example, Case 70-IP-2002, at 3 (Sept. 4, 2002) (interpreting Dec. 344) (Joseph E. Seagram \& Sons) (citing Case 30-IP-99 (Sept. 3, 1999) (interpreting Dec. 344)).

106 These forms appear to be a fairly recent phenomenon, suggesting that the ATJ created them after receiving many referrals that did not contain an adequate record.

107 See, e.g., Case 9-IP-95, at 2-4 (Sept. 19, 1995) (interpreting Dec. 85, Dec. 313, \& Dec. 344) (stating that the SIC had forgotten about its prior registration of a trademark, leading to the registration of two similar trademarks in the same category in violation of Andean law); Case 9-IP-97, at 2 (Feb. 4, 1998) (interpreting Dec. 344), discussed in 89 TRADEMARK REP. 252, 274 (1999) (chiding SIC for registering a trademark without investigating whether it conflicted with any previously registered trademarks and rejecting the agency's justification that no oppositions had been filed during the registration process).

${ }^{108}$ Case 39-IP-98, at 6 (Mar. 26, 1999) (interpreting Dec. 344) ("Siendo evidente que una asociación de Laboratorios Farmacéuticos tiene, prima facie, un interés legítimo en materia de patentes farmacéuticas para recurrir u oponerse en defensa de la norma lesionada.").
} 
Tribunal clarified and repeated the procedures that agency officials were to follow when reviewing contested IP applications. These procedures included strict adherence to Andean rules regulating oppositions, ${ }^{109}$ the obligation to justify the rejection of oppositions, ${ }^{110}$ responsibility to apply Andean IP standards with particular care when applications are contested, ${ }^{111}$ and the duty to provide adequate facts and legal analysis to enable both parties to challenge the agency's registration decision. ${ }^{12}$ These procedures fostered a hospitable climate for the fair and evenhanded adjudication of IP disputes.

Third, the Andean Tribunal has required IP agencies to justify their decisions with reasons. ${ }^{113}$ In any legal system, reasoned decision making cabins the discretion of public officials. ${ }^{114}$ But in countries where the rule of law is weak, the obligation to give reasons has a more powerful effect-it deters officials from circumventing or perverting the law by deciding cases on the basis of bribes, political influence, or "intuition." 115 The ATJ expressly recognized that domestic agencies were not free from political pressure. ${ }^{116}$ By repeatedly insisting that agency lawyers and administrators justify and explain their registration decisions in writing, the Tribunal not only bounded their discretion. It also helped to insulate the agencies from domestic politics and to create a constituency for compliance with its rulings.

The previous examples describe important procedural dimensions of the rule of law. The ATJ has also drawn upon its close relationship with the administrative agencies to fill gaps in substantive Andean IP rules. One striking example involves "coexistence agreements," contracts that allow two or more trademark owners "to set rules by which the[ir] marks can peacefully coexist" in the same market. ${ }^{117}$ In many jurisdictions, including the United States and several Latin American countries, such privately brokered agreements are presumptively valid. If two business competitors consent to coexist in the same territory, both of their trademarks are likely to be registered regardless of whether consumers would be confused by such parallel legal protection. ${ }^{118}$

${ }^{109}$ Case 5-IP-99, at 6-7 (Oct. 25, 2000) (interpreting Dec. 344).

${ }^{110} I d$. at $7-8$.

${ }^{111}$ Case 16-IP-2003, at 7 (Mar. 12, 2003) (interpreting Dec. 344).

112 Case 44-IP-2006, at 10 (May 3, 2006) (interpreting Dec. 344).

113 See, e.g., Case 35-IP-98 (Oct. 30, 1998) (interpreting Dec. 344) (instructing the national judge to determine whether the administrative agency had appropriately justified its decision). For the ATJ's view of what qualifies as an appropriately reasoned opinion, see Case 04-AN-97 (Aug. 17, 1998) (nullifying Junta Res. 435 (1996)).

${ }^{114}$ See Frederick Schauer, Giving Reasons, 47 STAN. L. REV. 633 (1995).

115 See, e.g., Case 28-IP-96, at 11-12 (Oct. 31, 1997) (interpreting Dec. 344) (stating that the determination of whether a trademark is famous "should not be the product of simple intuition" about a particular mark; rather, the determination of fame "shall be the product or the consequence of a previous analysis, procedure or investigation . . . along with the evidence presented by the parties").

${ }^{116}$ In Case 27-IP-95, the ATJ stressed the need for "administrative and economic autonomy to free officials from any kind of pressures or influences that derogate from the ends or purposes of the defense of a trademark for the owner as well as for the public or consumer." Case 27-IP-95, at 15 (Oct. 25, 1996) (interpreting Dec. 344). The Tribunal went so far as to state, in dictum, that the failure to provide such autonomy "implies an infringement that violates the ends and purposes of [Andean] laws." Id.

117 International Trademark Association, Glossary, available at <http://www.inta.org/>; see also Marianna Moss, Trademark "Coexistence" Agreements: Legitimate Contracts or Tools of Consumer Deception? 18 LOY. CONSUMER L. REV. 197, 209 (2005).

118 See, e.g., Moss, supra note 117, at 210-13 (reviewing U.S. law); John M. Murphy, The Confusing Similarity Standard in Mexican Trademark Law, 96 TRADEMARK REP. 1182, 1190 (2006) (reviewing Mexican law). 
Originally, Andean law was silent on coexistence agreements. The ATJ filled this gap by requiring IP agencies to review all such agreements to protect the interests of consumers. A subsequent Andean IP Decision appeared to contradict this doctrine. ${ }^{19}$ But the ATJ distinguished the potential conflict and reaffirmed its earlier position. Colombian and Peruvian agencies-whose mandates, as explained above, include both consumer protection and intellectual property-were sympathetic to the Tribunal's position. Although the agencies' proconsumer orientation initially triggered some grumbling by the trademark bar, resistance subsided after repeated rulings by the ATJ that were followed by national judges and administrators. ${ }^{120}$

The foregoing analysis reveals how the registration decisions of domestic IP agencies, appeals to national courts, and preliminary references to the ATJ, taken together, generated a positive feedback mechanism that helped build an effective IP rule of law. Early ATJ rulings improved the agencies' procedures, promoted reasoned decision making, clarified ambiguities in Andean rules, and helped to insulate officials from domestic politics. The resulting favorable legal climate for IP protection encouraged an increase in IP applications and appeals to national courts. The judges on those courts referred a growing number of cases to the ATJ, which further clarified Andean IP rules and administrative procedures. The cycle was completed when the Tribunal's case law was consumed by the same agencies whose registration decisions had spawned the first wave of ATJ litigation. This positive feedback mechanism was an important component of establishing IP rights as an effective rule-of-law island in the Andean Community.

\section{Enforcing Andean IP Rules in Response to National Violations}

A third feature of an effective rule of law is inducing changes in states' behavior that would not otherwise have occurred. Although the individuals we interviewed sometimes expressed disagreement with the ATJ's reasoning, they all attested that national judges and agency officials habitually comply with preliminary rulings, most of which interpret Andean legislation in the abstract without applying the law to the facts of the case at hand. But the ATJ has also been effective in politically high-profile cases challenging national laws as a violation of Andean IP rules. Three disputes in particular merit analysis, each of which involves the Tribunal's jurisdiction to review noncompliance complaints filed by private parties and the General Secretariat.

In the "pipeline" patent case, decided in 1996, the ATJ invalidated a bilateral agreement between Ecuador and the United States that granted patent protection to foreign pharmaceutical firms. In the "second use" patent case of 2001, the ATJ overturned a Peruvian decreeadopted in response to pressure by the U.S. pharmaceutical giant Pfizer-that authorized domestic IP agencies to grant second-use patents—including the lucrative second-use patent for Viagra—in contravention of Andean rules. The ATJ later overturned Ecuadoran and Venezuelan agency decisions awarding patents for Viagra. Last, in the "data protection" case,

\footnotetext{
${ }^{119}$ Dec. 486, Art. 136(f) (2000) (prohibiting the registration of trademarks that "consist of a sign that infringes the industrial property rights . . . of a third party, except where the consent of the latter has been obtained") (emphasis added).

120 See Interview with Mera Gómez, supra note 90. For examples of cases invalidating coexistence agreements, see SIC Res. 18176 ( July 30,2004), reprinted in COMPENDIO DE DOCTRINA, supra note 101, at 398 - 401; Annual Review, Twelfth Annual International Review of Trademark Jurisprudence, 95 TRADEMARK REP. 267, 348 (2005).
} 
decided in 2005, the Tribunal found fault with a Colombian decree-adopted under pressure from the United States - that protects the test data submitted by pharmaceutical manufacturers to national health agencies when seeking approval to market new medicines.

We describe these cases in detail to demonstrate that national courts and IP agencies initially followed government decrees that violated Andean law. These actors changed course, however, after the ATJ found the decrees in violation of Andean law and ordered the agencies to reverse decisions based on the decrees. And in two of the three disputes, national governments acquiesced in these reversals. The third case-data protection-was more contentious. Colombia argued that the ATJ's interpretation of Andean law was erroneous. But rather than defy the Tribunal's ruling, Colombia orchestrated the adoption of an "interpretive decision" using a procedure for legislative revision that the Tribunal itself had previously approved.

The essential point that ties all three cases together is that ATJ rulings have made it more difficult for member states to defect from Andean policies in response to demands by the United States and U.S. corporations for stronger IP protection rules. Such pressures are unrelenting, and over time the United States has won some concessions. In these three areas of intellectual property, however, Andean countries have successfully resisted pressures to which many of their regional neighbors have succumbed. As a result, the Andean Community has been better able to maintain key elements of the region's distinctive and balanced approach to reconciling the social and economic needs of developing countries with the interests of IP rights holders.

Enforcing the ban on "pipeline" patents. During the first two decades of the Andean Pact, its member states did not award patents for pharmaceutical products-a position shared by most developing countries. ${ }^{121}$ In the early 1990s, however, the member states lifted this ban as part of their broader effort to conform Andean rules to multilateral IP standards. Rather than fully embracing patents for drugs, Andean governments phased in protection incrementally. They recognized patents for new drugs developed after the revision of Andean rules. But, adopting a doctrine known as "absolute novelty," the member states refused to protect medicines patented in other countries during the years when it was impossible to apply for a pharmaceutical patent in the Andean countries. Although many of these foreign drugs were in the production "pipeline" before the change in Andean law, the region's governments nevertheless refused to recognize them. ${ }^{122}$

The United States took a position that favored the pharmaceutical companies. It pressured Andean countries to recognize so-called pipeline protection for these preexisting patented

121 See SELL, supra note 45, at 191-92; Pedro Roffe with Christoph Spennemann \& Johanna von Braun, From Paris to Doha: The WTO Doha Declaration on the TRIPS Agreement and Public Health, in NEGOTIATING HEALTH: INTELlECTUAL PROPERTY AND ACCESS TO MEDICINES 9, 13 (Pedro Roffe et al. eds., 2006).

122 Pipeline patents protect inventions that were ineligible for protection under prior domestic legislation:

For example, if a country begins granting pharmaceutical patents in 1995, a drug that was invented in 1991 would not have been eligible for a patent at the time it was new. Strict interpretation of novelty would make such a drug ineligible for patents in 1995 too, because by the time the patent scope was changed to make drugs patentable the drug in question did not satisfy the novelty requirement. Yet some countries opted to grant patents to older drugs in the "pipeline," provided they were not already on the market.

Ken Shadlen, The Politics of Patents and Drugs in Brazil and Mexico: The Industrial Bases of Health Activism, Global Dev. \& Envt'l Inst. Working Paper No. 07-05, at 6 (Dec. 2007), available at < http://www.ase.tufts.edu/gdae/ Pubs/wp/07-05PoliticsOfPatents.pdf $>$. 
drugs. Most Andean member states resisted this pressure. ${ }^{123}$ In 1993, however, Ecuador and the United States signed a bilateral treaty granting pipeline protection. Ecuador's Congress never ratified the treaty, but the country's president adopted a decree to implement it. Relying on this decree, over the next two years the Ecuadoran IP agency awarded twenty-three pipeline patents to foreign pharmaceutical manufacturers such as Pfizer and Novartis.

In response, several domestic producers of generic drugs challenged the presidential decree. An Ecuadoran administrative court referred the case to the ATJ, which issued a preliminary ruling holding that Andean law follows the absolute novelty requirement. ${ }^{124}$ Nevertheless, the administrative court rejected the ATJ's ruling and upheld the national decree instead.

Attorneys on the staff of the General Secretariat were following the litigation in Ecuador closely. After the administrative court's decision, the secretariat filed a noncompliance action against Ecuador alleging that the pipeline decree and the court's ruling violated Andean law's absolute novelty requirement. This was the first noncompliance action that the secretariat brought to the ATJ. ${ }^{125}$

Ecuador defended the domestic decree as falling within the discretion granted to member states to adopt domestic legislation or international agreements that "strengthen the industrial property rights provided for in" Andean Decision 344. ${ }^{126}$ The General Secretariat countered that the Ecuadoran decree contradicted an unambiguous limitation on Andean IP protection and created an incentive for foreign firms to seek pharmaceutical patents in Ecuador but not in other member states. The ATJ sided with the Andean officials. ${ }^{127}$ It interpreted the word "strengthen" in a teleological fashion, reasoning that national laws and treaties must complement the regional IP system, not contradict it. Ecuador had thus violated Andean IP rules "by establishing an exceptional regime ... granting advantages to patenting in its own country, in a manner that was unfair under the common regime applied in the other Andean countries." 128 The Tribunal also categorically rejected Ecuador's claim that "an international commitment [could] be invoked as a reason to validate noncompliance with a prior Community obligation." 129

Compliance with the ATJ's judgment played out over the next decade in several venues. Within weeks of the ruling, the government adopted a new decree revoking the prior law recognizing pipeline patents. Relying on the new decree, the domestic IP agency rejected at least 120 pending applications from foreign businesses seeking to register pipeline patents.

Frustrated foreign patent applicants challenged the agency's rejections. When national judges referred these cases to the ATJ, the Tribunal supported the agencies. It also reaffirmed its prior ruling, stating: "The 'pipeline' principle is not part of Andean law and is contrary to that of 'absolute novelty,' which must be applied by the competent authorities. Any patent

${ }^{123}$ Manrique, supra note 46, at 217.

${ }^{124}$ Case 6-IP-94 (Dec. 9, 1994) (interpreting Dec. 344).

${ }^{125}$ General Secretariat officials chose this case to demonstrate their support for the ATJ. They also wanted the Tribunal to penalize a clear violation of Andean rules and thereby to affirm the supremacy of the Andean Community's balanced approach to IP protection in the area of pharmaceutical patents. Interviews with Rosell, supra note 34 .

${ }^{126}$ Dec. 344, Art. 143 (1993).

127 Case 1-AI-96 (Oct. 30, 1996).

${ }^{128}$ Manrique, supra note 46, at 217.

${ }^{129}$ Case 1-AI-96, supra note 127 , at 30. 
requested on the basis of the pipeline principle must be denied or, if granted, nullified."130 Since the first ATJ pipeline ruling in 1996, Ecuadoran IP agencies have not granted any additional pipeline patents. ${ }^{131}$ Nor, our interviews disclosed, have the administrative agencies of the other four member countries. The agencies thus played a key role in enforcing Andean law. ${ }^{132}$

Without Andean intervention, Ecuador would likely have succumbed to demands from the United States to protect pipeline patents. For example, Mexico and three of the four members of Mercosur-Argentina, Brazil, and Uruguay-acceded to U.S. pressure to recognize such patents during roughly the same period. ${ }^{133}$

Enforcing the ban on second-use patents. The Andean requirement of absolute novelty for inventions also bars recognition of so-called second-use patents-patents initially granted for one purpose but later found to be beneficial for an unrelated purpose. Andean Decisions 344 and 486 categorically reject second-use patents, stating that "[p]roducts or processes already patented and included in the state of the art . . . may not be the subject of new patents on the sole ground [that the product was] put to a use different from that originally contemplated by the initial patent." 134

In the 1990s, the American pharmaceutical company Pfizer discovered that its heart medication pyrazolpyrimidinones (Viagra) had the side effect of treating male impotence. Latin America promised to be a lucrative market for Viagra. Notwithstanding clear Andean rules to the contrary, Pfizer filed second-use patent applications in all of the Andean countries in an effort to prevent the sale of generic copies of the drug throughout the region.

In Peru, the INDECOPI patent office applied Andean law and rejected three applications by Pfizer. A few months later, in June 1997, President Alberto Fujimori issued a decree that purported "to facilitate the proper application of" various articles of Decision 344. ${ }^{135}$ Article 4 of

${ }^{130}$ Case 25-IP-2002, supra note 104, at 18.

${ }^{131}$ U.S. Trade Representative, Third Report to THE CONGRESS ON THE Operation OF THE ANDEAN TRADE PREFERENCE ACT 37 (Jan. 31, 2001), available at < http://www.ustr.gov/asset/Trade_ Development/Preference_Programs/ATPA/asset_upload_file215_3783.pdf?ht $=>$.

132 The situation with respect to the twenty-three pipeline patents registered prior to the ATJ's ruling was more complex. In 1998 the Ecuadoran national director of industrial property confirmed the validity of these patents. In response, the ATJ concluded that the director's decision upholding the registrations was a further infringement of Andean law, and it imposed sanctions on Ecuador. Proceso 1-AI-96, at 1-2 (July 28, 1999) (imposing sanctions reducing, from 60 to 50 percent, the national origin preference of the FOB value of Ecuadoran products until Ecuador revoked the twenty-three pipeline patents). The following year, an Ecuadoran administrative court ruled that the government was required to nullify all acts that violated the ATJ's ruling. Case 25-IP-2002, supra note 104, at 19 . We have been unable to confirm that the IP agency has revoked these twenty-three pipeline patents. However, we infer from the fact that the ATJ continues to receive occasional preliminary references concerning these patents that not all of them have been nullified.

133 See CHRISTOPHER SCOTT HARRISON, THE POLITICS OF THE INTERNATIONAL PRICING OF PRESCRIPTION DRUGS 103-10 (2004) (describing how the United States pressured Argentina and Brazil to protect pipeline patents for pharmaceuticals in 2000 and 1997, respectively); Shadlen, supra note 122, at 6-9, 15-19 (same, for Mexico in 1991). Uruguay recognized pipeline protection in 1999, see Law of Patents, Art. 127, Law No. 17.164 of Sept. 2, 1999, Diario Oficial, Sept. 2, 1999 (Uru.), available at <http://gpi.espaciolibre.net/2007/04/07/ uruguay-ley-n\%C2\%BA-17164-patentes-de-invencion-modelos-de-utilidad-y-disenos-industriales $>$. Chile, a founding member of the Andean Pact that withdrew in 1976 and returned as an associate member in 2006, has thus far resisted U.S. pressure to protect pipeline patents. See Jeffrey Lax, Note, A Chile Forecast for Accession to NAFTA: A Process of Economic, Legal and Environmental Harmonization, 7 CARDOZO J. INT'L \& COMP. L. 97, 112 (1999).

${ }^{134}$ Dec. 486, Art. 21; Dec. 344, Art. 16.

135 Supreme Decree No. 010-97-ITINCI, EL PERUANO, June 6, 1997, at 149,830, available at<http://www. glin.gov/view.action?glinID $=52500>$. 
the decree recognized second-use patents, including new uses of existing drugs. ${ }^{136}$ Several officials and attorneys we interviewed indicated that they were suspicious of the decree's origins, stating that the law "appeared out of nowhere."

Immediately thereafter, Pfizer asked INDECOPI to reexamine its applications to patent Viagra. Relying on the new law, the agency granted the applications in January 1999. Pfizer then threatened to sue Peruvian drug companies that were manufacturing or selling generic copies of Viagra. With domestic litigation looming, the Association of Pharmaceutical Industries of National Origin (ADIFAN) filed a complaint with the General Secretariat alleging that Peru had violated Decision 344's ban on second-use patents. The General Secretariat upheld the complaint and, after Peru failed to overturn the decree, submitted the case to the ATJ. In a reflection of the case's high political salience, ADIFAN participated as an interested third party in support of the General Secretariat, while Pfizer and the Association of National Pharmaceutical Laboratories joined the case in support of Peru. In a judgment issued in September 2001, the ATJ upheld the complaint and the Andean ban on second-use patents. As a result, it directed Peru "to leave without effect the patent granted to" Pfizer. ${ }^{137}$

ADIFAN then asked INDECOPI to revoke the Viagra patent. Following its normal procedures, the agency did so several months later. According to INDECOPI officials, adhering to the Andean Tribunal's judgment was a straightforward matter: "When the ATJ tells us what the supreme interpretation of the law is, then our own interpretation is void." Since the Viagra case, the agency has not granted any second-use patents. ${ }^{138}$

INDECOPI officials related that they were dismayed by the political interference in their decision making. Nevertheless, before the ATJ's ruling, the officials refused to ignore the Peruvian decree. The Peruvian government never repealed the law, but neither did it pressure INDECOPI to enforce it, ${ }^{139}$ suggesting that government officials had been willing to circumvent Andean law, yet unwilling to fight Andean officials or repudiate the ATJ on behalf of Pfizer.

Litigation in Venezuela and Ecuador followed a similar pattern. The IP agency in each country registered a second-use patent for Viagra prior to the ATJ ruling against Peru, and national associations of generic drug manufacturers turned to the Andean legal system to challenge the registrations. When the General Secretariat and the ATJ reaffirmed their prior rulings, the administrative agencies reversed their positions and invalidated the patents. ${ }^{140}$ In Colombia, by contrast, the administrative agency was bolder. It rejected Pfizer's application, leading the company to appeal to the Council of State, which requested a preliminary ruling. The Tribunal

\footnotetext{
${ }^{136}$ Article 4 provided that "a distinct use included in the state of the art shall be the subject of a new patent if it complies with" the normal patent requirements of novelty, inventive step, and industrial applicability. Id.; see also Pascale Boulet, Patents and Medicines in Peru 4 (Campaign for Access to Essential Medicines, Nov. 2001), at $<$ http://www.aislac.org/pdf/documentos_interes?10_1_report.pdf >; Ena Matos Jaqui, Las patentes de segundo uso, LA HORA (Ecuador) (n.d.), available at <http://www.dlh.lahora.com.ec/paginas/judicial/PAGINAS/D. Autor.4.htm>.

${ }^{137}$ Case 89-AI-2000, at 40 (Sept. 28, 2001) (interpreting Dec. 344 \& SG Res. 406).

138 Interviews with officials in INDECOPI's National Institute for the Defense of Competition and the Protection of Intellectual Property, Lima (June 21, 2007).

${ }^{139} \mathrm{Id}$.

140 See Case 01-AI-2001, at 39 (June 27, 2002) (interpreting Dec. 344, SG Res. 424, 459) (judgment against Venezuela); Case 34-AI-2001, at 51-52 (Aug. 21, 2002) (interpreting Dec. 344) (judgment against Ecuador); see also Carlos Pacheco \& María Milagros Nebrada, Venezuela: How to Protect Inventions of Use, MANAGING INTELL. PROP. (Supp. 2006), available at <http://www.managingip.com/?Page $=17 \& I S S=22626 \& S I D=654998>$.
} 
reiterated its interpretation of Andean law and the Colombian court implemented the ATJ's decision. ${ }^{141}$

The ATJ's response to one argument in favor of second-use patents highlights its insistence on the preeminence of Andean IP rules not only over conflicting national laws and bilateral treaties, but also over multilateral agreements. In the noncompliance suit against Venezuela, Pfizer argued that the Andean countries, as members of the WTO, were obligated to interpret the region's IP rules in harmony with the TRIPS Agreement, which, it claimed, required protection of second-use patents. ${ }^{142}$ The ATJ categorically rejected this argument. It reasoned that the member states had transferred regulatory authority to the Andean Community to establish common regional IP rules whose application is mandatory and "neither depends on, nor is subject to compatibility with, other international laws."143

The end result of this wave of litigation was that all domestic IP agencies in the Andean Community denied or annulled patents for Viagra. ${ }^{144}$ This regionwide refusal to recognize seconduse patents remains a major irritant to the U.S. pharmaceutical industry. The industry's 2008 Special 301 Report to the Office of the U.S. Trade Representative places the blame for this state of affairs squarely on the ATJ:

The Andean Court of Justice (ACJ) [has] issued several legal opinions ... forcing Andean Community members to refuse recognition of patents for second uses .... Such decisions constitute law in Bolivia, Colombia, Ecuador, and Peru. Andean member countries have either been compelled by the ACJ not to grant second use patents or chosen to honor Andean Community obligations ... . The failure to provide patents for second uses particularly affects the pharmaceutical industry, which has dedicated substantial research dollars to evaluating additional therapeutic benefits of known molecules (second uses) in order to provide effective solutions for unsatisfied medical needs. The ACJ position is dispositive on the issue and no further domestic appeals/remedies are possible. ${ }^{145}$

Without the ATJ's interventions, Andean countries would likely have succumbed to external pressures to grant second-use patents. Indeed, the legal landscape looks quite different elsewhere in Latin America. El Salvador, Guatemala, Honduras, Mexico, and Paraguay recognize second-use patents; Argentina, Chile, Panama, and Uruguay do so in certain instances; and the status of such patents in Brazil is uncertain. Only Costa Rica, the Dominican Republic, and Nicaragua share the Andean Community's prohibition of all second-use patents. ${ }^{146}$

The politics of data protection and the reversal of an ATJ ruling. The third and most recent Andean IP noncompliance dispute concerns the test data that drug companies submit to

${ }^{141}$ See Multinacional Pfizer no puede patentar principio activo del potenciador sexual Viagra en Colombia, ELTIEMPO.COM, Jan. 6, 2009, at < http://www.eltiempo.com/colombia/justicia/multinacional-pfizer-no-puedepatentar-principio-activo-del-potenciador-sexual-viagra-en-colombia_4743402-1>.

${ }_{142}$ Case $01-\mathrm{AI}-2001$, supra note 140 , at 11.

${ }^{143} \mathrm{Id}$. at 36-37 (quoting Case 89-AI-2000, supra note 137).

${ }^{144}$ Pacheco \& Nebrada, supra note 140 , at 3.

145 Pharmaceutical Research and Manufacturers of America (PhRMA), Special 301 Submission 236 (2008), available at <http://www.ustr.gov/assets/Trade_Sectors/Intellectual_Property/Special_301_Public_Submissions_ 2008/asset_upload_file109_14495.pdf $>$.

146 The enactment dates of the relevant national laws are as follows: Argentina (2000), Chile (2005), El Salvador (2005), Guatemala (2000), Honduras (1999), Mexico (1994), Nicaragua (2000), Panama (1998), Paraguay (2001), and Uruguay (1999). For Brazil, see Maristela Basso, Intervention of Health Authorities in Patent Examination: The Brazilian Practice of the Prior Consent, 1 INT'L J. INTELL. PROP. MGMT. 54, 56-57 (2006). 
domestic health ministries when seeking approval to market new medicines. ${ }^{147}$ The pharmaceutical industry favors laws that give the companies an exclusive right to control such data. Absent such protection, the industry claims, competitors can unfairly rely on the drug companies' data without the expense in time and resources of conducting their own safety tests. ${ }^{148}$

Contentious disputes over data protection have been waged in the Andean Community for more than a decade. ${ }^{149}$ Decision 344, adopted in 1993, prohibited the disclosure of unpublished test data - a form of legal protection mandated by the TRIPS Agreement. ${ }^{150}$ But the Decision also made this protection exclusive for five years, exceeding the TRIPS requirements. ${ }^{151}$ In this respect, the protection of test data contrasted with other Andean IP rules, which incorporated many of the flexibilities specified by TRIPS for developing countries.

During negotiations to revise Decision 344, governments were sharply divided over whether to modify the region's data protection rules. On the one hand, the region was home to a large generics industry that sold drugs at prices substantially lower than those for patented medicines. ${ }^{152}$ On the other, the United States and U.S. pharmaceutical firms were exerting strong pressure on Andean states to provide for a five-year period of exclusivity for test data in a draft U.S.-Andean trade treaty and in the proposed Free Trade Agreement of the Americas. ${ }^{153}$ Indeed, the U.S. Trade Representative characterized exclusive data protection as "one [of its] key implementation priorit[ies]." 154

Colombia, which faced strong pressure to accede to American demands, ${ }^{155}$ pushed for a provision permitting member states to grant a period of exclusive protection for test data. The four

${ }^{147}$ See Dolores Cullen, Data Protection: The New IP Frontier-An Overview of Existing Laws and Regulations, 5 J. GENERIC MED. 9, 9-10 (2007).

148 See Razvan Dinca, The "Bermuda Triangle" of Pharmaceutical Law: Is Data Protection a Lost Ship? 8 J. WORLD INTELL. PROP. 517, 520-21 (2005).

${ }^{149}$ As a result of these contestations, the current and former governmental officials whom we interviewed requested anonymity. We therefore do not provide the names of the individuals whom we interviewed concerning data protection issues.

${ }^{150}$ Dec. 344, Art. 78; TRIPS, supra note 44, Art. 39.3.

${ }^{151}$ Dec. 344, Art. 79; see also European Generic Medicines Association, TRIPS Article 39.3 Does Not Require Data Exclusivity Provisions-A Critical Issue for Access to Medicines (Position Paper, July 2000), available at $<$ http://www.egagenerics.com/doc/ega_trips39.3_2000.pdf $>$.

${ }^{152}$ Interviews at the Colombia Ministry of Trade, Industry \& Tourism, Bogotá (Sept. 14, 2007) [hereinafter Colom. Trade Ministry Interviews]; Interview with Dr. Alberto Bravo Borda, executive president of Asociación de industrias farmacéuticas colombianas (ASINFAR), Bogotá (Sept. 14, 2007); see also Oxfam International, Song of the Sirens, Why the US-Andean FTAs Undermine Sustainable Development and Regional Integration 11, Oxfam Briefing Paper, June 2006, available at <http://www.oxfam.org.uk/what_we_do/issues/trade/downloads/bp 90 andeanftas.pdf $>$ (stating that "generics supply two thirds of the national market" in Colombia at "on average, a quarter the cost of their brand-name equivalents").

153 See, e.g., Gaëlle P. Krikorian \& Dorota M. Szymkowiak, Intellectual Property Rights in the Making: The Evolution of Intellectual Property Provisions in U.S. Free Trade Agreements and Access to Medicine, $10 \mathrm{~J}$. WORLD INTELL. PROP. 388 (2007).

${ }^{154}$ Office of the U.S. Trade Representative, 2003 Special 301 Report-Executive Summary at 6 (May 1, 2003), available at <http://www.ustr.gov/Document_Library/Reports_Publications/2003/2003_Special_301_Report/ Section_Index.html $>$.

155 The United States threatened to exclude Colombia from the Andean Trade Preference Act — a statute that provides duty-free access to U.S. markets — and to cut economic aid (at the time totaling $\$ 7.5$ billion) that the Colombian government relied upon to help reduce internal conflicts, combat the narcotics industry, and stimulate the economy. Diana Rodríguez Franco, The Globalization of Intellectual Property Rights: The Politics of Law and the Transformation of National and Transnational Legal Fields-The Struggles Behind the IP Chapter of the Colombian-U.S. Free Trade Agreement 25-26 (2008) (unpublished paper on file with authors). 
other countries countered that Andean IP rules should not exceed the TRIPS standards. ${ }^{156}$ In the end, the new legislation-Decision 486 of 2000 — tracked the language of its predecessor and required protection of "undisclosed test or other data . . . against unfair commercial use." This language was followed, however, by an ambiguous final sentence to the effect that member states "may take steps to guarantee the protection provided for under this article." 157

Relying on this sentence, Colombia enacted a decree in 2002 that granted up to five years of exclusive protection for test data. ${ }^{158}$ The Association of Colombian Pharmaceutical Industries (ASINFAR) promptly challenged the decree, but the General Secretariat upheld the law as permitted under the above-quoted sentence. ${ }^{159}$ ASINFAR appealed to the ATJ, which rejected the secretariat's interpretation and held that the Colombian decree violated Decision $486 .{ }^{160}$ The ATJ's disagreement with the secretariat is itself noteworthy. In all prior IP noncompliance cases, the secretariat had found national laws to be incompatible with Andean rules, and the ATJ had upheld its findings. The data protection ruling thus placed the two Andean actors in opposition to each other for the first time.

In its analysis of the decree, the Tribunal reasoned that the member states had made a deliberate choice to abolish the period of exclusivity that had previously existed in Andean law. ${ }^{161}$ It also reasoned that data protection, like other forms of intellectual property, must be interpreted in light of the Community's broader interests in public health. ${ }^{162}$ These interests precluded Colombia from enacting data protection rules that deviated from the regional standard. ${ }^{163}$

The fallout from the ATJ's ruling was immediate. As noted above, all the Andean countries (except Bolivia) were in the midst of negotiating a regional trade treaty with the United States, which had demanded a five-year period of exclusivity for test data. Ecuador and Venezuela opposed the provision, but Peru and Colombia had accepted it. ${ }^{164}$ After the ATJ ruling,

156 The ATJ described this negotiating history in detail in Case 114-AI-2004, at 36-41 (Dec. 8, 2005) (interpreting Dec. 486).

157 Dec. 486, Art. 266.

158 Supreme Decree 2085 of 2002, Diario Oficial, Sept. 19, 2002 (Colom.), available at <http://www. presidencia.gov.co/prensa_new/decretoslinea/2002/septiembre/19/dec2085190902.pdf>; see also Natalia Tobón, Colombia-New Found Protection for Test Data, PATENT WORLD, Dec. 2002 (on file with authors).

159 GS Res. 817, at 10 (Apr. 14, 2004).

${ }^{160}$ Case 114-AI-2004, supra note 156. The case drew widespread attention from the pharmaceutical and generics industry associations, which participated in the case as interested third parties. The Asociación de Laboratorios Farmacéuticos (ALAFAR) supported the petitioner ASINFAR, and the Asociación de Laboratorios Farmacéuticos de Investigación (AFIDRO) supported Colombia.

${ }^{161}$ Our interviews revealed this to be a particular point of contention and criticism of the Tribunal. According to Colombian IP attorneys and officials in the Ministry of Trade, Colombia had agreed to the cryptic final sentence of Article 266 only after it received assurances from the other member states that it could adopt a five-year exclusive right to protect test data. Colom. Trade Ministry Interviews, supra note 152. This tacit understanding was not, however, memorialized in the drafting history, which indicated that Colombia's efforts to retain a period of exclusive data protection were unsuccessful. See Case 114-AI-2004, supra note 156, at 41.

${ }^{162}$ Case 114-AI-2004, supra note 156, at 41 (“[T] he Community interest that must regulate the marketing of pharmaceutical products . . . is directed to the protection of public health and the improvement of the standard of living of the inhabitants of the subregion.").

${ }^{163} \mathrm{Id}$. at 49 ("[T] he protection of test data or undisclosed information is protected by Decision 486, and consequently, member countries cannot protect their data in a different way and, much less, set a period of exclusivity not contemplated in the Community legislation.").

164 See Disagreement over Data Protection Holding up Andean-US FTA, 9 BRIDGES WKLY. TRADE NEWS DIG., Sept. 28, 2005, at 4, at <http://ictsd.net/i/news/bridgesweekly/6192/>. 
government officials told us that this provision was "off the table." 165 In response, the Colombian Ministry of Foreign Trade issued a press release defending the decree. It also asked the other governments-acting in their capacity as members of the Andean Commission- to affirm that the decree was consistent with Andean law. ${ }^{166}$

All prior Decisions had been approved by consensus, but on this issue the member states were deadlocked. After several attempts to reach agreement failed, the Commission scheduled another meeting for April 2006. Bolivia and Venezuela were unable to vote at that meeting because they had not paid their membership dues. In their absence, the remaining three countries agreed to adopt Decision 632. The legislation "clarifies the intent of the legislators . . by establishing that each Member Country shall have the authority to choose the means for protecting test data, including the possibility of establishing time periods" of exclusive protection $^{167}$ - a retroactive validation of the Colombian data protection decree.

Whether the Commission's action should be seen as a rebuke to the Andean Tribunal is a different matter. A document issued by the U.S. pharmaceutical industry asserts that Decision 632 "quashed the decision of the Court." ${ }^{168}$ But there is evidence to the contrary. Colombia never contemplated ignoring the ATJ's ruling. Officials emphasized to us that "Colombia is a country that obeys Andean Tribunal decisions" and that, as a result, they considered only legal means to preserve the data protection decree. They also feared that noncompliance might lead the ATJ to impose sanctions, as it had done in the pipeline case against Ecuador. ${ }^{169}$ Decision 632 reflects this concern for legality. It never mentions the Tribunal's 2005 ruling. Instead, it refers to an earlier case in which the ATJ stated that

only the [Andean] Commission ... is authorized to make what is known in legal doctrine as an "authentic interpretation," by issuing another legal norm at the same level or with the same hierarchy. ... .

... This later legislative effort is intended to clarify the material content of a law that in the legislators' opinion was unclear or that had been subject to differing interpretations.... ${ }^{170}$

The member states thus emphasized that the precedents of the ATJ itself authorized them to correct its mistaken interpretation of Decision 486's ambiguous text and drafting history.

Whatever its consequences for the Tribunal's authority, the data protection dispute exacerbated an already tense political climate in the region. Trade negotiations broke down in late 2005 when first Peru and later Colombia negotiated bilateral treaties with the United States, both of which require a five-year period of exclusivity for test data. ${ }^{171}$ Two weeks after the

165 Colom. Trade Ministry Interviews, supra note 152 (describing events following ATJ data protection ruling).

166 See Pharma International, Special 301 Report 2006 -Colombia, available at < http://international.phrma. org/latin_america/colombia/special_301_report_2006_colombia $>$ (by subscription) (describing press release).

167 Dec. 632, pmbl. (Apr. 6, 2006), available in Eng. at < http://www.comunidadandina.org/ingles/normativa/ D632e.htm>.

${ }^{168} \mathrm{PhRMA}$, Special 301 Submission 2007 at 257, available at <http://members.phrma.org/international/ PhRMA_Special_301_Submission_2007.pdf $>$.

169 Colom. Trade Ministry Interviews, supra note 152.

${ }^{170}$ Dec. 632, supra note 167, pmbl. (quoting Case 7-AI-99, at 18 (Nov. 12, 1999)).

${ }^{171}$ See Rosa Castro Bernieri, Intellectual Property Rights in Bilateral Investment Treaties and Access to Medicines: The Case of Latin America, 9 J. WORLD INTELL. PROP. 548, 563-64 (2006); Krikorian \& Szymkowiak, supra note 153 , at $400-01$. 
Commission adopted Decision 632, Venezuela withdrew from the Andean Community. "President Chavez stated publicly that the reason for the withdrawal was the entry of other member countries into free trade agreements with the United States . . ." ${ }^{172}$ An official in Colombia's foreign trade ministry concurred, but characterized Decision 632 as the "last straw" in precipitating Venezuela's break with the regional integration pact. ${ }^{173}$

Decision 632 brings Andean countries closer to the United States' preferred position, in that it permits - but does not require-member states to grant a term of exclusive protection for test data. In the remainder of Latin America, however, a five-year period of exclusivity is rapidly becoming the norm, as countries capitulate to U.S. pressure or ratify bilateral treaties mandating such protection. In contrast, Bolivia, Ecuador, and Venezuela do not provide for such protection, nor have they negotiated bilateral treaties with the United States. ${ }^{174}$

\section{The Andean Tribunal's Contribution to Building an IP Rule of Law}

In the preceding three sections, we analyzed three facets of an effective rule-of-law island for IP in the Andean Community. First, our evidence demonstrates that the Andean legal system has created valuable and enforceable property rights that are strengthened by the ability of private parties to seek ATJ rulings that interpret Andean IP laws. Second, ATJ rulings have changed national court and administrative practices relating to IP rights, especially by requiring agency officials to create an adequate factual record, to justify their decisions with reasons, and to provide clear and fair procedures for contesting parties. Third, the ATJ has been effective as a bulwark against powerful foreign interests that have pressured individual governments to go beyond the WTO-compatible rules that Andean IP law embodies. As a result, Andean IP rules retain many limitations and restrictions that other Latin American countries abrogated in response to pressure from the United States. ${ }^{175}$

These three facets of the IP rule-of-law island are interrelated and mutually reinforcing. Early ATJ litigation clarified the content of Andean IP rules and improved the quality of agency decision making. These advances made the acquisition of IP rights more attractive for private parties, who filed a growing number of applications for trademarks and patents. These filings, in turn, increased the agencies' revenue, and thus their autonomy. ${ }^{176}$ Over time, agency officials came to rely on Andean jurisprudence to carry out their core functions. Consultations with the General Secretariat over revisions of Andean IP rules, and ATJ rulings that tempered IP rights in the name of consumer protection, further bolstered the agencies' fidelity to the Andean legal system. ${ }^{177}$

\footnotetext{
${ }^{172}$ U.S. Trade Representative, National Trade Estimate Report on Foreign Trade Barriers 621 (2007), available at $<$ http://www.ustr.gov/>.

173 Colom. Trade Ministry Interviews, supra note 152.

${ }^{174}$ See Cullen, supra note 147, at 9-10 \& tbl. 1 (reviewing data protection rules in all developing countries, including those in Latin America, and describing U.S. successful effort to incorporate data protection in bilateral trade and investment treaties).

175 This aspect of the ATJ's practice meets the standard definition of effectiveness used in IR literature, which measures whether an international rule or institution induces "desired changes in behavior that otherwise would not have occurred." Raustiala, supra note 6, at 396.

${ }^{176}$ Recall that budgets of several IP agencies were funded by patent and trademark application fees. See supra text at note 53 .

177 See supra text at notes $58-59 \& 119-20$.
} 
Disputes between trademark applicants and opponents were principally responsible for these developments. ${ }^{178}$ But these disputes between private actors laid the groundwork for the agencies to act as compliance constituencies in high-profile cases challenging domestic patent decrees as contrary to Andean law. The agencies' actions increased the cost of noncompliance in these cases. To flout the ATJ, national executives would have been required to do more than simply ignore the Tribunal's rulings: they would have been compelled to interfere with the settled rules and decision-making procedures of the domestic agencies themselves.

To be sure, the ATJ's effectiveness is not unlimited. The data protection dispute may reveal one outer edge of the IP rule-of-law island. The case is exceptional, however, in several ways. The first concerns the content of Andean law. Andean Decisions are very clear in disallowing second-use patents; for data protection, the rules were undeniably cryptic and subject to conflicting interpretations. The General Secretariat sided with the Colombian government and it continues to believe that the ATJ's ruling misconstrued Andean law. Second, the ATJ handed down its ruling during a period of sharp ideological divisions in the region, as three of the five member states_-Bolivia, Ecuador, and Venezuela_-were distancing themselves from the liberalizing policies of the Washington Consensus, and the other two-Colombia and Peruwere coming under increasing pressure from the United States to protect test data. Third, unlike the pipeline and second-use-patent litigation, the data protection case involved an issue within the purview of national health ministries; and unlike the IP agencies, these ministries had no prior relationship with the Tribunal and no professional stake in enforcing Andean law. ${ }^{179}$ For all of these reasons, the data protection dispute is different from other IP cases where ATJ rulings successfully rebuffed political efforts to circumvent Andean IP rules.

A second outer edge of the IP rule-of-law island involves Bolivia and Venezuela, whose courts, as noted above, have referred almost no preliminary references to the ATJ. ${ }^{180}$ The subjects we interviewed attributed the lack of referrals from Bolivia to its low level of economic development, the country's weak judicial and administrative systems, and a limited volume of IP-related foreign investment. ${ }^{181}$

The picture for Venezuela is less clear. At the administrative level, the government created a new IP agency, SAPI, in 1997. According to its former legal counsel, SAPI applied Andean IP law to review patent and trademark applications. ${ }^{182}$ Although the agency initially granted a second-use patent to Pfizer, it did comply with the ATJ's decision on such patents. ${ }^{183}$ This record is similar to those of IP agencies in other member states. The practice of the national courts, however, is quite different. As in Peru and Ecuador, Venezuelan courts refused to refer

\footnotetext{
178 See supra text at note 66 (giving the subject matter breakdown of ATJ preliminary rulings).

179 See Health Ministry of Peru, Evaluation of Potential Effects of the Free Trade Agreement Being Negotiated with the United States on Access to Medicines (2005), available at <http://www.citizenstrade.org/pdf/ peruvianhealthministry_impactofiponaccesstomeds_042005.pdf $>$ (unofficial translation of conclusions) (analyzing the consequences of increased data protection for the cost of medicines without mentioning Andean law or ATJ rulings).

180 See supra text at note 74 and fig. 2, p. 15.

${ }^{181}$ E.g., Interview with Olarte, supra note 61; Interview with Augusto Rey, executive director, Asociación nacional de laboratorios farmacéuticos (ALAFARPE), Lima (June 19, 2007).

${ }^{182}$ Interview with Colmenter, supra note 52.

183 See Case 01-AI-2001, supra note 140; Pacheco \& Nebrada, supra note 140.
} 
appeals of agency decisions to the ATJ. But in contrast to what happened in those two countries, in Venezuela no private actor complained about this refusal to the General Secretariat. The prospect of such complaints diminished with the election of President Hugo Chávez in 2001, and it vanished with Venezuela's withdrawal from the Andean Community in 2006. Strikingly, however, SAPI and Venezuelan judges continue to apply Andean IP law, suggesting that, under different political conditions, they might eventually have referred IP cases to the ATJ. ${ }^{184}$

\section{WHY ANDEAN LITIGATION HAS NOT SPILLED OVER TO OTHER ISSUE-AREAS}

Our coding of ATJ cases in part I indicated that more than 90 percent of preliminary rulings involved IP issues. This percentage has remained constant over time, revealing that private actor litigation has not spilled over to other issue-areas. The existence of such spillovers is critical to explanations of the ECJ's success. ${ }^{185}$ Why, then, has the explosion of IP litigation not reached other areas regulated by the Andean Community? To answer this question, we must investigate "dogs that did not bark," an inquiry that is inherently more suggestive than definitive. $^{186}$

We identify three principal arguments for why intellectual property remains an island. First, the Andean IP rules (Decisions 311, 313, 344, and 486, see table 1, p. 9) are detailed and precise; outside intellectual property, Decisions often contain loopholes or hortatory language that preserve national discretion. For example, the Andean telecommunications policy requires governments to create access to scarce frequencies. But the requirement is "without prejudice to such national provisions as each member country may establish," allowing governments to privilege national carriers owned by politically powerful families. ${ }^{187}$ Agricultural and livestock legislation permits member states to decide whether applying Andean rules is feasible and efficacious. ${ }^{188}$ And the Decision harmonizing value-added taxes is replete with transitory provisions, exemptions for certain sectors and actors, and rules that grandfather existing national tax systems. ${ }^{189}$

These differences in Andean law reveal that governments have an interest in maintaining common IP rules, but are only weakly committed to Andean market integration. This tepid commitment reflects the reality that trade with nonmembers (especially the United States, the European Community, Brazil, Argentina, and Mexico) is far more economically important

${ }^{184}$ U.S. Dep't of State, 2007 Investment Climate Statement-Venezuela, available at <http://www.state.gov/ e/eeb/ifd/2007/80762.htm>.

185 See, e.g., Anne-Marie (Slaughter) Burley \& Walter Mattli, Europe Before the Court, 47 INT'L ORG. 41, 60 (1993).

${ }^{186}$ The analysis in this part builds upon the framework set forth in Karen J. Alter, The European Union's Legal System and Domestic Policy: Spillover or Backlash? 54 INT'L ORG. 489 (2000).

${ }^{187}$ Dec. 462, Art. 23 (May 25, 1999); see also Arts. 20, 22. According to a lawyer who requested anonymity, the Colombian government invoked this provision to the advantage of the Alcatel corporation, which has close links to powerful families in that country.

188 Dec. 328, Arts. 15, 20 (Oct. 22, 1992).

${ }^{189}$ Dec. 599, Arts. 7, 13, 14, 16,17, 28, 30, 32, 33, 37, 39 (July 12, 2004). For more detailed analysis, see Luis A. Arias et al., The Harmonization of Indirect Taxes in the Andean Community, Inter-Am. Dev. Bank Occasional Paper SITI-07 (2005), available at <http://idbdocs.iadb.org/wsdocs.getdocument.aspx?docnum $=781731>$. 
than inter-Andean trade, which has accounted for roughly 10 percent of total trade since the 1990s. ${ }^{190}$

Competing trade regimes also sap member states' commitment to the Andean integration process. Latin American countries have negotiated free trade agreements for at least half a century. Recently, Mercosur-a South American customs union initially comprising Argentina, Brazil, Paraguay, and Uruguay - has acted as a powerful centrifugal force that pulls Andean member states away from each other. Andean countries have sought to manage this competition through a strategy of "open regionalism." ${ }^{191}$ Over the last decade, all five Andean countries have become associate members of Mercosur, and in 2002 the two regional organizations entered into their own free trade pact. ${ }^{192}$ Open regionalism promotes member states' trade interests, but it also diminishes incentives to deepen Andean integration and favors building closer economic relations with other countries in Latin America.

A second explanation for why intellectual property remains a rule-of-law island is that the ATJ has been reluctant to interpret Andean rules purposively. Consider a few examples. The Tribunal has rejected attempts by private litigants to invoke the spirit or goals of the Cartagena Agreement to restrict member states' freedom of action in areas not directly regulated by Andean Decisions. ${ }^{193}$ In addition, the ATJ refused to police the scope of permitted exemptions under the Andean Free Trade Program. ${ }^{194}$ Similarly, the ATJ held in a 2002 preliminary ruling

\footnotetext{
${ }^{190}$ Inter-Andean trade accounted for only 3 to 5 percent of total trade during the Andean Pact period. See Avery \& Cochraine, supra note 27, at 183; Hojman, supra note 26; Evolución del proceso de integración 1969-1999, Comunidad andina [CAN] Doc. SG/di219/Rev.1, at 28 (Apr. 26, 2000) (on file with authors). In the last decade, trade between Andean countries has become marginally more important, peaking at 13 percent in 1998 but declining to less than 10 percent a few years later. See MigUEL RODRÍGUEZ MENDOZA, TRADE RULES IN THE MAKING: CHAllenges In Regional AND Multilateral Negotiations 96 (1999); Mikio Kuwayama, Latin American South-South Integration and Cooperation: From a Regional Public Goods Perspective 14, Economic Commission for Latin America and the Caribbean, Comercio Internacional Series No. 50 (2005). A related factor is that intraregional trade consists primarily of low-value-added finished goods, as opposed to intermediary products used in the production of high-value-added goods. Producers of these finished goods may gain from lowering intra-Andean trade barriers, but they may also face increased competition from producers of similar products in neighboring Andean countries, and thus be less enthusiastic about lowering market barriers. See Kuwayama, supra, at 33; Avery \& Cochraine, supra, at 191-92.

${ }^{191}$ Chris Brummer, The Ties that Bind? Regionalism, Commercial Treaties, and the Future of Global Economic Integration, 60 VAND. L. REV. 1349, 1353 \& n.7 (2007) (defining “"open' regionalism as that which extends the terms and benefits of regional integration to the rest of the world and 'closed' regionalism [as] that [which] locks in special benefits for members"); see also Mauricio Baquero-Herrera, Open Regionalism in Latin America: An Appraisal, 11 L. \& BUS. REV. AM. 139 (2005).

192 Acuerdo de complementación económica No. 56, CAN-Mercosur, Dec. 6, 2002, available at <http://www. sice.oas.org/Trade/MRCSR/acMerAns.asp $>$. The dates of associate membership for Andean countries are Bolivia (1999), Peru (2003), and Ecuador, Colombia, and Venezuela (2004). Venezuela became a full member of Mercosur after withdrawing from the Andean Community in 2006. In 2004 the region's presidents formed the South American Community of Nations. This new continental integration project seeks "the gradual convergence" of the Andean Community, Mercosur, Chile, and other South American countries. For a more detailed discussion, see Samuel A. Arieti, The Role of Mercosur as a Vehicle for Latin American Integration, 6 CHI. J. INT'L L. 761, 762-65 (2006).

193 See KAREN J. ALTER, Jurist Advocacy Movements in Europe: The Role of Euro-Law Associations in European Integration (1953-1975) [hereinafter Alter, Jurist Advocacy Movements], in THE EUROPEAN COURT'S POLITICAL POWER: SELECTED ESSAYS 61, 81-84 (2009) (discussing Cases 1-AI-87, supra note 30; 1-IP-90 (Sept. 18, 1990); and 3-IP-93 (July 13, 1993) involving regulation of the aluminum industry); Saldías, supra note 27, at 21-28 (reviewing ATJ decisions rejecting attempts by litigants to challenge national regulations that conflicted with an Andean Community policy goal, such as market liberalization).

${ }^{194}$ Instead, it held that "the domestic judge is the one with the authority to determine if the product is included . . in the Free Trade Program." Case 3-IP-93, supra note 193, at 9.
} 
that it lacked the authority to examine anticompetitive practices if they had no adverse effects in other Andean countries. ${ }^{195}$ The ATJ also refused to allow preliminary references from administrative agencies that carried out judicial functions. ${ }^{196}$ In this regard, the ATJ stands in sharp contrast to its jurisdictional twin-the European Court of Justice-which is famous for interpreting legal lacunae in ways that attract new cases and promote market and legal integration in Europe. ${ }^{197}$ The Tribunal's more modest conception of its own powers reduces the incentives and opportunities for private actors to enforce Andean Decisions through litigation. ${ }^{198}$

These narrow rulings may well have a basis in Andean law, and they may faithfully reflect member states' preferences. But when it comes to intellectual property, the ATJ has not been nearly as reticent. Instead, it has acted more like the ECJ by drawing upon national practices to build Andean IP doctrine and defend regional IP rules against conflicting national and international standards. ${ }^{199}$

The third explanation for the persistence of intellectual property as an island is that the ATJ is not supported by a broader set of private or public compliance constituencies. With respect to private actors, the ATJ lacks a critical mass of litigants and attorneys willing to bring lawsuits to enforce Andean tariffs, taxes, customs, and other non-IP rules. The absence of interlocutors has roots in the region's higher education system. Andean Community law is not taught in most universities, either as a free-standing course or as a section of administrative or constitutional law courses. As a result, awareness of the Andean legal system remains limited. Most attorneys do not view the system as relevant to their practice, and activists, scholars, and nongovernmental organizations do not perceive Andean litigation as having strategic value or providing opportunities for advocacy. ${ }^{200}$

The ATJ also lacks national judicial support. As discussed in part I, national courts had to be convinced to make references to the ATJ in IP cases. Moreover, national judges have hesitated to expand their involvement with the ATJ beyond areas exclusively governed by Andean

195 Case 87-IP-2002, at 13 (Nov. 13, 2002) (interpreting various Decisions and an SG resolution).

${ }^{196}$ In 1999 the INDECOPI administrative tribunal attempted to refer a case to the ATJ. The INDECOPI performs many of the same administrative review functions that in Colombia are performed by the Council of State-the administrative court that has referred two-thirds of the cases on the ATJ's docket. Yet Andean judges rejected the INDECOPI referral, adopting the formalist position that only judicial bodies may request preliminary rulings. We found no written record of this decision, but its existence was confirmed by several Peruvian attorneys, judges, and government officials. The ATJ reversed course in 2007, ruling that IP agencies could refer cases following a final administrative decision. Case 14-IP-2007 (Mar. 21, 2007) (interpreting the term "domestic judge" in the Revised ATJ Treaty, supra note 35, to include an administrative agency that carries out judicial functions). This change is likely to expedite ATJ review of agency registration decisions by obviating the need for appeals to national courts.

197 See Weiler, supra note 15.

${ }^{198}$ For an additional explanation of the ATJ's relative modesty, see Alter, Jurist Advocacy Movements, supra note 193.

${ }^{199}$ For example, the ATJ's jurisprudence on trademark coexistence agreements is entirely judge made, and it reflects the reality that INDECOPI and SIC have portfolios that include protecting consumer rights. See supra text at notes $117-20$.

${ }^{200}$ E.g., Interview with Firma Romero Arteta Ponce, supra note 85; Interview with Olarte, supra note 61; Interviews with Rosell, supra note 34; Interview with Tangerife, supra note 61.

There is still the option of filing a noncompliance action with the General Secretariat, and, through it, to the ATJ. It is possible that lawyers prefer this route. Noncompliance complaints involve a wider variety of issue-areas and have increased in number over time, suggesting that such complaints may be a more attractive way for private actors to challenge government policies. Whether this route is effective, however, is a different question. The Andean legal system authorizes sanctions if a member state refuses to implement an ATJ noncompliance ruling. A large number of such rulings have resulted in sanctions, which suggests that compliance is spotty. This issue merits further research. 
rules. ${ }^{201}$ In interviews, judges emphasized that the member states and the General Secretariat, not national judges, were responsible for ensuring compliance with Andean rules. They further claimed that they need not refer cases that concern only domestic laws. ${ }^{202}$ This limited conception of the national judges' role may simply reflect an early stage of the integration process. Indeed, this reticence is similar to that observed in Europe in the $1960 s .{ }^{203}$ But it is also directly at odds with the ATJ Treaty, which requires referrals not only of cases in which an Andean rule "is litigated," but also of those in which Andean law "should be applied." 204

Another missing compliance constituency is a set of autonomous domestic actors within the state that are committed to following Andean rules. In part I we discussed the creation of domestic IP agencies in the 1990s. IP administrators were differently situated than other administrators in certain important respects. ${ }^{205}$ First, the agencies they worked for were either wholly new or substantially reinvented. With no entrenched habits or established track record, and few domestic actors with knowledge of international IP law, the agencies were open to drawing on Andean Community expertise. Second, IP agencies were fairly well resourced. They received initial funding from the international financial institutions that promoted market liberalization, and they benefited from the material and technical support of WIPO. Several agencies also have an independent funding source-fees paid by IP applicants. Finally, intellectual property is a specialized area of legal practice with international career prospects. It attracts ambitious lawyers and trade negotiators who study outside the region, and thus themselves become part of a global community of actors who believe in the rule of law for the subject. These resources and actors give the IP agencies the know-how, incentive, and opportunity to do their job well. They also provide agency administrators with the autonomy to embed Andean IP rules in their administrative practices.

These reasons for the failure of Andean integration to extend beyond the realm of intellectual property remain somewhat ad hoc. What we can say is that there appears to be a wholesale lack of demand for enforcing Andean law and that the factors undermining broader integration are self-reinforcing, creating a negative feedback loop that inhibits the penetration of Andean rules into national legal systems. ${ }^{206}$ The lack of governmental commitment to expand economic relations between the member states also decreases the incentives of private actors to build intra-Andean economic ties and allows national judicial and administrative reticence to act as a barrier to litigants using the Andean legal system to promote their interests.

${ }^{201}$ In other areas of Andean integration, such as taxes and customs, domestic rules and institutions predated the Andean Pact and have continued to exist alongside it. Interview with Mauricio A. Plazas Vega Carrera, professor of law, Colegio mayor de Nuestra Señora del rosario de Bogotá, and founder, Mauricio A. Plazas Vega Abogados \& Compañía, Bogotá (Sept. 14, 2007). For national actors in these areas, the Andean legal system appears to be more disruptive than facilitative, forcing changes in practices and partially divesting national actors of their legal and interpretive authority. For additional discussion, see Helfer \& Alter, supra note 68.

${ }^{202}$ E.g., Interview with judges of the Council of State, supra note 67; Interview with Judge Vásquez Cortez, supra note 67.

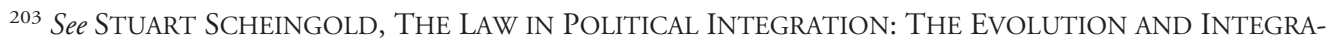
TIVE IMPLICATIONS OF REGIONAL LEGAL PROCESSES IN THE EUROPEAN COMMUNITY (1971).

${ }^{204}$ Revised ATJ Treaty, supra note 35, Art. 33.

${ }^{205}$ For a discussion of the difficulties that many administrative agencies in Latin America face, see Inter-Am. Dev. Bank, The Politics of Policies: Economic and Social Progress in Latin America 67 (2006), available at <http://www. iadb.org/res/ipes/2006/index.cfm?language $=$ En\&parid $=1>$ (comprehensive empirical analysis of Latin American administrative agencies concluding, inter alia, that " $t]$ he transition from authoritarian to democratic regimes has been linked to a certain tendency to further subordinate the bureaucracy to political control").

${ }^{206}$ On negative feedback loops, see Alter, supra note 186, at 512-15. 


\section{THE ANDEAN EXPERIENCE AND THE INCREASING JUDICIALIZATION OF INTERNATIONAL LAW}

For scholars of Latin American legal institutions or intellectual property law, understanding the ATJ's contribution to building an IP rule-of-law island in the Andean Community is interesting in its own right. But the implications of the Tribunal's issue-specific success story extend far beyond intellectual property and the geographic confines of the Andes.

In this part, we evaluate competing theories of effective international adjudication in light of the Andean experience. Such an evaluation is especially important and timely because, as we explain below, tribunals in other regional treaty systems may be developing their own distinctive issue- or country-specific islands of international adjudication.

\section{Assessing Alternative Theories of Effective International Adjudication}

The last two decades have witnessed a global rush of international judicial construction. As one scholar has aptly noted, "[I]t still comes as a surprise to many lawyers and scholars who do not specialize in international law to learn that there are now more than fifty international courts, tribunals, and quasi-judicial bodies, most of which have been established in the past twenty years." ${ }^{207}$ In addition to courts and tribunals, these institutions include quasi-judicial review mechanisms, hybrids of adjudication and arbitration, and novel blends of international and domestic judicial authority. ${ }^{208}$

As the number of these juridical bodies has grown, scholars have advanced three different theories to explain the conditions under which they will be effective. The ATJ's contribution to building the rule of law in the Andean Community - but only in the area of intellectual property-brings forth new evidence to evaluate these competing theories.

The first theory posits institutional design as the key explanatory variable. Scholars who endorse this approach stress factors such as judicial independence, compulsory jurisdiction, and standing and other judicial access rules in distinguishing effective institutions. ${ }^{209}$ A clear hypothesis emerges from this theoretical framework. Tribunals with design features that "penetrat[e] the surface of the state" and allow international judges to "interact directly with the principal players in national legal systems" are more likely to attract a steady stream of cases from private litigants or national courts, which, in turn, will act as compliance constituencies for the tribunals' rulings. ${ }^{210}$

A second approach, grounded in principal-agent theory, links effectiveness to the strategic actions of judges. Some of the work in this school analyzes the legal, political, and discursive

\footnotetext{
${ }^{207}$ Jenny S. Martinez, Towards an International Judicial System, 56 STAN. L. REV. 429, 430 (2003).

208 The literature analyzing the proliferation of international courts and tribunals is vast. For a recent survey, see Jacob Katz Cogan, Competition and Control in International Adjudication, 48 VA. J. INT'L L. 411 (2008).

209 See Karen J. Alter, Delegation to International Courts and the Limits of Recontracting Power, in DELEGATION AND AGENCY IN INTERNATIONAL ORGANIZATIONS 312, 331-34 (Darren Hawkins et al. eds., 2006).

${ }^{210}$ Helfer \& Slaughter, Effective Supranational Adjudication, supra note 13, at 277; see also Miles Kahler, Conclusion: The Causes and Consequences of Legalization, 54 INT'L ORG. 661, 675 (2000) ("compliance constituencies"); Alter, supra note 5, at 44-45.
} 
constraints that together create a "strategic space" that defines the boundaries within which tribunals can be effective. ${ }^{211}$ For other principal-agent scholars, by contrast, the key explanatory variable is whether states have adequately cabined the activist tendencies of the women and men who serve on these tribunals. International judges, this argument continues, are professionally predisposed "to depart from their limited roles in order to expand their own and their courts' authorities." 212 To combat these inherently activist tendencies, the states must establish control mechanisms to deter or penalize judicial overreaching. ${ }^{213}$ Absent such controls, activist tribunals will trigger a backlash by states, which will withhold consent to their jurisdiction ex ante, withdraw from that jurisdiction ex post, or refuse to comply with their judgments. ${ }^{214}$

A third group of scholars uses liberal international relations theory to tie effectiveness to the political and legal conditions prevailing in the states subject to a tribunal's jurisdiction. Where democratic regimes, independent national judiciaries, and robust civil societies are weak or nonexistent, these scholars argue, international courts - even those possessing broad jurisdiction and capacious formal powers-will be neither active nor effective. ${ }^{215}$ Seen from this perspective, the prospects for effective international adjudication in many regions of the world are less than promising.

What insights does the Andean experience offer to help evaluate these three theories of effectiveness? With respect to tribunal design, the ATJ Treaty establishes a preliminary reference procedure that creates a direct link between national judges and their Andean colleagues. Preliminary references are responsible for more than 90 percent of ATJ rulings, constituting additional evidence that effectiveness (at least within a confined policy space) may be enhanced by design features that allow international judges to interact with private litigants and national courts. But, for the reasons explained in part III, the preliminary reference procedure has generated only a trickle of cases involving other Andean laws. The dearth of private actor litigation outside the area of intellectual property reveals that preliminary references and other modes of private access do not in themselves suffice to establish effective international adjudication.

${ }^{211}$ Richard H. Steinberg, Judicial Lawmaking at the WTO: Discursive, Constitutional, and Political Constraints, 98 AJIL 247, 249 (2004); see also Karen J. Alter, Agents or Trustees? International Courts in Their Political Context, 14 EUR. J. INT'L REL. 33, 46-48 (2008); Helfer \& Slaughter, supra note 10, at 942-54.

${ }^{212}$ Cogan, supra note 208, at 415; Posner \& Yoo, supra note 12, at 7 (asserting that " $[\mathrm{t}$ ] ribunals are likely to be ineffective when they neglect the interests of state parties and, instead, make decisions based on moral ideals, [or on] the interests of groups or individuals within a state"); see also ROBERT H. BORK, COERCING VIRTUE: THE WORLDWIDE RULE OF JUDGES 10 (2003) ("Judges of international courts . . . are continuing to undermine democratic institutions and to enact the agenda of the liberal Left or New Class.").

213 See, e.g., Paul B. Stephan, Courts, Tribunals and Legal Unification-The Agency Problem, 3 CHI. J. INT'L L. $333(2002)$.

${ }^{214}$ Cogan, supra note 208, at 440; see also Laurence R. Helfer, Overlegalizing Human Rights: International Relations Theory and the Commonwealth Caribbean Backlash Against Human Rights Regimes, 102 COLUM. L. REV. 1832 (2002) (explaining why three Caribbean countries withdrew from the jurisdiction of human rights tribunals after "overlegalization" of their treaty obligations generated domestic opposition to compliance with their decisions).

215 See, e.g., Andrew Moravcsik, Explaining International Human Rights Regimes: Liberal Theory and Western Europe, 1 EUR. J. INT'L REL. 157, 179-80 (1995) (arguing that "effective international institutions often presuppose established democratic legal and political orders and robust civil societies, within which domestic actors can work to assure compliance with international norms" and noting the absence of such conditions in Latin America); Keohane, Moravcsik, \& Slaughter, supra note 12, at 478 (positing that liberal democracies will be more receptive to efforts to "embed international law in domestic legal systems"); Anne-Marie Slaughter, International Law in a World of Liberal States, 6 EUR. J. INT’L L. 503, 532-33 (1995) (predicting greater likelihood of compliance with international rules by countries that are liberal democracies). 
The insights of the Andean case study for principal-agent theories are also noteworthy. Although the ATJ was explicitly modeled on the ECJ, we found numerous examples where Andean judges, unlike their European counterparts, demonstrated little appetite for modest expansions of their authority even when expansive rulings were unlikely to generate political opposition. ${ }^{216}$ This quiescence suggests that factors other than control mechanisms may explain the extent of judicial activism. ${ }^{217}$ Admittedly, in the data protection case the member states arguably punished the ATJ for issuing a politically problematic ruling (although not per se for being too activist). ${ }^{218}$ The case may be an outlier for the reasons discussed in part II above. Or it may reveal in the Andean context the outer limit of international court independence that principal-agent theorists expect.

For scholars who cite domestic political and legal factors to explain when international tribunals succeed or fail, the effectiveness of the ATJ - even when confined to intellectual property-will be surprising. Notwithstanding a wave of reforms in the 1990s, Andean countries have continued to experience political crises that put "democratic regime[s] at risk and frequently lead to significant backsliding." ${ }^{219}$ In addition, the absence of fully independent national judiciaries ${ }^{220}$ and the presence of opportunities for political intervention in domestic legal systems (not to mention instances of corruption or bribery) reveal that Andean countries are "weak states" 221 in which the "the rule of law is partial and incomplete, and . . respect for civil rights and property rights is limited." 222

Scholars who view liberal democratic regimes and a strong domestic commitment to the rule of law as precursors to effective international adjudication would expect the ATJ's effectiveness to be severely impeded by these characteristics. We shared these expectations when we began to investigate the Andean Community's legal system. But our research revealed that the ATJ

216 See supra part III. For additional evidence, see Alter, Jurist Advocacy Movements, supra note 193; Saldías, supra note 27.

217 See Alter, supra note 209.

${ }^{218}$ It is unclear whether the member states' response to the data protection decision will influence future ATJ rulings. The sequence of events is similar to the European Barber Protocol, in which member states added a provision to the Maastricht Treaty to limit an ECJ ruling involving equal pay for men and women. Analyses of ECJ jurisprudence following the Barber Protocol found that this so-called sanction had little discernible effect on the Court's case law. See MARK A. POLLACK, THE ENGINES OF EUROPEAN INTEGRATION: DELEGATION, AGENCY, AND AGENDA SETTING IN THE EU 359-65 (2003); Alec STONE SweET, THE Judicial CONSTRUCTION OF EUROPE 172-75 (2004).

${ }^{219}$ Gerardo L. Munck, Democratic Politics in Latin America: New Debates and Research Frontiers, 2004 ANN. REV. POL. SCI. 437, 449.

220 See Linn Hammergren, Fifteen Years of Judicial Reform in Latin America: Where We Are and Why We Haven't Made More Progress 5 (UN Dev. Programme 2002), available at <http://www.pogar.org/publications/judiciary/ linn 2 /index.html\#intro $>$ ("Latin American judiciaries have tended to be less functionally relevant and at the same time more politically penetrated than their European counterparts. While they have sometimes been manipulated by the powerful, they have just as often been ignored.").

221 This domestic weakness is consistent with, and indeed a justification for, Latin American states' longstanding support for regional organizations that promote adherence to international law. See ARIE MARCELO KACOWICZ, THE IMPACT OF NORMS IN INTERNATIONAL SOCIETY: THE LATIN AMERICAN EXPERIENCE, 1881-2001, at 55 (2005) (stating that "the attempt to focus the intraregional international relations of Latin America in legalistic terms can be derived from the structural and domestic weaknesses . . . of the Latin American states").

222 Solimano, supra note 8, at 38; see also Kaufmann et al., supra note 8, at 4280 (reporting the results of a World Bank rule-of-law index that ranks Andean countries in the bottom 25 percent of all states); Andrés Solimano, Introduction and Synthesis, in POLITICAL ECONOMY OF THE ANDEAN REGION, supra note 8, at 1, 1 (stating that "[i]nternational rankings of quality of institutions as measured by indices of rule of law, effectiveness of regulation, control of corruption and others place the Andean group in a relatively low place" relative to other Latin American countries). 
is an effective international tribunal, albeit only within the IP issue-area, principally because domestic IP agencies act as compliance constituencies for its rulings. ${ }^{223}$

The behavior of these administrative agencies and their interactions with Andean judges and officials are perhaps our study's most important findings, findings that are relevant to all three theories of effective international adjudication. When institutional design proponents analyze a tribunal's jurisdictional rules, when principal-agent scholars map international judges' strategic space, and when liberal international relations theorists consider how international courts can forge links with domestic actors, they rarely take into account the growth and importance of the regulatory state. ${ }^{224}$

The Andean experience in constructing an IP rule-of-law island suggests the need to consider whether administrative agencies have an interest in enforcing international rules and tribunal decisions, as well as the autonomy to do so. Agency officials can serve as a crucial conduit for compliance that bypasses other governmental institutions. Just as links between the ECJ and lower domestic courts in Europe made it possible for those courts to circumvent the resistance adopted by some national appellate judges toward the ECJ, ${ }^{225}$ so links between independent administrative agencies and tribunal judges may open up an avenue for effective international adjudication where national courts are passive or even hostile to international authority.

The ability of administrative agencies to act as compliance constituencies also helps to explain when international tribunals are activist or expansionist. In the Andean context, ATJ judges are bold when they expect support for their rulings from Andean officials and from the IP agencies. When such support is lacking, the judges become formalists, narrowly construing implied limits on member states' freedom of action and enforcing Andean law only where rules are clear and violations are manifest. The more general theoretical point is that for international judges to be willing to innovate or fill in lacunae in treaty texts, they need a domestic constituency that will support their efforts.

Finally, our analysis uncovers a striking example of how an international legal system can help to bolster and stabilize the rule of law in developing countries by targeting a particular state institution. Recall that few national courts were willing to send referrals to the ATJ when it opened for business. With only a handful of exceptions, the IP agencies were the Tribunal's only interlocutors. In responding to the many questions agency officials posed, the ATJ improved their decision-making procedures, increased their fidelity to Andean rules, and helped to insulate them from domestic political pressure. The General Secretariat reinforced these trends by soliciting the agencies' advice about revising Andean IP Decisions, giving administrators a stake in applying Andean rules. Significantly, these actions occurred well before most national judges had accepted the ATJ's authority. This sequence of events suggests

\footnotetext{
${ }^{223}$ This suggests that liberal democracy is not an all-or-nothing category. Fragile democracies may have areas where the rule of law functions effectively, while robust democracies can have weak spots. See O'Donnell, supra note 103 , at 1362 .

${ }^{224}$ The growth of the administrative state is a global phenomenon. For a recent analysis that emphasizes the proliferation of administrative agencies in Latin America, see Jacint Jordana, Toward a Latin American Regulatory State? The Diffusion of Autonomous Regulatory Agencies Across Countries and Sectors, 29 INT'L J. PUB. ADMIN. 335, 336-66 (2006). Our findings also suggest the need for additional research to examine the role of independent agencies in shaping the quality of democracy and the rule of law- a factor neglected in previous comparative studies about the quality of democracy. See Munck, supra note 219.

${ }^{225}$ Alter, supra note 186, at 504-05.
} 
that a tribunal put in place when some governmental institutions are weak or resistant to international adjudication can itself contribute to building the rule of law, albeit within a defined institutional space. As we explain below, this phenomenon may be emerging in regions beyond the Andean Community.

\section{Emerging Islands of International Adjudication in Other Regional Systems}

A second implication of the Andean experience relates to how international tribunals can establish a foothold in countries whose legal systems are deficient or weak in some respect. Domestic conditions comparable to those prevailing in the Andean countries can be found in many parts of the world. If an island of effective international adjudication can develop in one region where democratic regimes are not fully entrenched, the rule of law is weak, and judges are not fully independent, other islands may arise in the growing number of nations subject to the jurisdiction of international courts and tribunals.

Two recent examples suggest that such islands may be emerging in other regional treaty systems. In the early 1990s, the Economic Community of West African States (ECOWAS) - a regional agreement between fifteen West African nations-created a Court of Justice to help promote economic integration. The court was inactive for more than a decade. In 2005 the member states granted private parties access to the tribunal for the first time and expanded its subject matter competences. ${ }^{226}$ Later that year, a group of politicians in Nigeria asked the court to review allegations of human rights violations relating to national elections in that country. NGOs and individuals have since filed a stream of new human rights complaints against several member states, with the result that the ECOWAS court is increasingly "assuming jurisdiction over human rights matters" in West Africa. ${ }^{227}$

Another example concerns the Organization for the Harmonization of Business Laws in Africa (OHADA). The organization's Common Court of Justice and Arbitration, created in 1995, exercises jurisdiction over sixteen francophone African nations that have adopted identical commercial codes. Its judges preserve the uniformity of these laws by issuing advisory opinions requested by OHADA officials, member states, or national courts, and by reviewing appeals from domestic courts of last instance. ${ }^{228}$ On paper, the OHADA court's "powers and prerogatives" have been described as "unique in the world." 229 In practice, however, many

${ }^{226}$ ECOWAS-CCJ, Court of Justice of the Economic Community of West African States, at <http://www. aict-ctia.org/courts_subreg/ecowas/ecowas_home.html>.

${ }^{227}$ Ibrahima Kane \& Ahmed C. Motala, The Creation of a New African Court ofJustice and Human Rights, in THE AFRICAN CHARTER ON HUMAN AND PEOPLES' RigHTS 406, 439 (Malcolm Evans \& Rachel Murray eds., 2d ed. 2008); see also Innocent Anaba, SERAP, CDHR Ask Gambia Govt to Obey Ecowas Court Judgment, VANGUARD (Nig.), June 28, 2008, available in 2008 WLNR 12118179 (describing efforts of two NGOs to pressure the Gambia to comply with an ECOWAS court ruling ordering the release of a journalist and awarding compensation for unlawful detention); Lydia Polgreen, Court Rules Niger Failed by Allowing Girl's Slavery, N.Y. TimES, Oct. 28, 2008, at A6 (describing a tribunal ruling ordering Niger to pay $\$ 19,000$ in damages for failing to protect a young woman sold into slavery at age twelve); Lillian Okenwa, ECOWAS Court Must Uphold Citizenship, Human Rights, THIS DAY (Nig.), Aug. 29, 2006, available at 2006 WLNR 15044380 (reporting statement by NGO Open Society Initiative West Africa that "there is a signal role for the Court of Justice of ECOWAS . . . in upholding the citizenship and human rights of West Africans").

228 See Boris Martor, NANetTe Pilkington, David SEllers, \& SÉbastien Thouvenot, Business LAW IN AFRICA: OHADA AND THE HARMONIZATION PROCESS 9-12 (2002).

${ }^{229}$ OHADA-CCJA, Court of Justice of the Organization for the Harmonization of African Business Law, at $<$ http://www.aict-ctia.org/courts_subreg/ohada/ohada_home.html > [hereinafter OHADA-CCJA]. 
national judges "are protective of their own authority" and do "not send[ ] all their businessrelated cases to the [court]" or refuse to implement the OHADA court's rulings. ${ }^{230}$ The one potential exception to this trend is the Côte d'Ivoire, where the court has its seat. According to a recent study, over 90 percent of the OHADA court's caseload comes from that country ${ }^{231}$ - a striking parallel to the ATJ's first decade when only Colombia referred cases to the Tribunal. ${ }^{232}$ Equally noteworthy are the good relations that international and Ivoirian judges have developed, a fact that has encouraged the relatively large number of referrals. ${ }^{233}$ It is not yet clear, however, if OHADA case law has come to shape national practices concerning corporate law in the same way that ATJ jurisprudence shapes national practices concerning IP rules. ${ }^{234}$

The nascent islands of international adjudication described in these two examples are defined by subject matter and geography. It is too soon to know whether the increases in international judicial activity within these boundaries will be effective or will bolster the domestic rule of law. The Andean experience suggests, however, that the African tribunals will need to cultivate domestic compliance constituencies — such as national human rights institutions or national bar associations - that are either part of the state or well positioned to influence its actions. But even at this early juncture, the emergence of these islands, together with the island fostered by the ATJ, raises the hope that international courts and tribunals may contribute to "building the rule of law 'in parts," " institution by institution and issue-area by issue-area. ${ }^{235}$

\section{CONCLUSION}

Few scholars and practitioners are aware that the Andean Tribunal of Justice is one of the most active international courts in a world increasingly populated by international courts and tribunals. This fact alone is striking. The ATJ interprets the laws and regulations of the Andean Community - a marginally successful regional integration pact created by five small developing nations on the mountainous western edge of South America. More unusual still are the cases on the ATJ's docket, which is dominated by disputes relating to trademarks, patents, and other IP rights. Within the Andean Community, intellectual property is principally regulated at the regional rather than the national level. But Andean legislation covers a host of other subjects that have generated far less international litigation.

${ }^{230}$ Claire Moore Dickerson, Harmonizing Business Laws in Africa: OHADA Calls the Tune, 44 COLUM. J. TRANSNAT'L L. 17, 57, 70 (2005) [hereinafter Dickerson, OHADA Calls the Tune]. The larger barriers seem to be businesses themselves, which make decisions based on local norms rather than OHADA legal rules. Claire Moore Dickerson, The Cameroonian Experience Under OHADA: Business Organizations in a Developing Economy, 112 BUS. \& SOC'Y REV. 191, 201 (2007) [hereinafter Dickerson, Cameroonian Experience].

${ }^{231}$ Dickerson, OHADA Calls the Tune, supra note 230, at 58 n.164 (citing interview with Seydou Ba, president of the OHADA Court); see also OHADA-CCJA, supra note 229 (stating that Côte d'Ivoire was the source of 116 of the 162 cases referred to the OHADA court between 1998 and 2003).

${ }^{232}$ See supra text at note 69 \& fig. 2 (illustrating history of national variation in patterns of referrals to the ATJ).

${ }^{233}$ Dickerson, OHADA Calls the Tune, supra note 230, at $57 \mathrm{n} .162$ (citing interviews with OHADA and Ivoirian judges).

${ }^{234}$ For an analysis of OHADA's influence outside the Côte d'Ivoire, see Dickerson, Cameroonian Experience, supra note 230 , at 207-09.

235 Becker, supra note 50, at 20. This insight dovetails with recent empirical research demonstrating that, even in Europe, the opportunities to use international litigation to challenge domestic laws and policies vary by country, subject matter, and the material resources of public and private actors. See, e.g., Lisa Conant, Individuals, Courts, and the Development of European Social Rights, 39 COMP. POL. STUD. 76 (2006); Rachel Cichowski, Courts, Rights and Democratic Participation, 39 COMP. POL. STUD. 50 (2006). 
We were surprised by the large number of IP-related cases that national courts refer to the Andean Tribunal. Even more striking, however, was our finding that the ATJ has contributed to building an effective rule of law for intellectual property in a region of relatively weak national legal systems. We measured effectiveness along three different dimensions. First, the Andean legal system and Andean litigation have created economically valuable and enforceable private property rights. Second, ATJ rulings have dramatically improved the decision-making procedures of domestic IP administrative agencies, bolstering their autonomy, increasing their fidelity to the rule of law, and balancing property rights against the public interest. Third, the ATJ has provided a mechanism for private parties, Andean officials, and domestic IP agencies to counter individual member states that seek to circumvent the region's distinctive approach to IP protection.

As a result of these three developments, IP protection in the Andean Community looks different than it does elsewhere in Latin America — a difference that has both external and internal dimensions. Externally, the regional IP system has preserved its substantively distinct elements in part because the ATJ has helped Andean countries to resist pressure from the United States to expand IP protection for foreign corporations. Internally, the Tribunal's more than fourteen hundred rulings have helped to establish intellectual property as a rule-of-law island in which private parties, domestic agencies, and national courts seek the ATJ's guidance on unsettled issues of Andean law and habitually follow Andean IP law as interpreted by the Tribunal.

Although the extent to which Andean litigation remains confined to a single subject is remarkable, the concentration of international litigation on a relatively limited number of issues may be more common than is widely believed. ${ }^{236}$ The circumscribed success of the Andean legal system thus offers fresh evidence to evaluate and refine three theories-institutional design, judicial strategy, and domestic political and legal context-that seek to identify the conditions under which international tribunals succeed or fail. It also suggests that other international tribunals can establish a foothold in countries where the domestic rule of law is weak.

How the Andean legal system and the IP rule-of-law island will evolve in the future remains uncertain. The restructured Andean Community has existed for just over a decade and the expansion of ATJ litigation took place even more recently. If the member states continue to harmonize laws at the regional level and tighten the standards they contain, private actors who benefit economically from these laws may seek to challenge nonconforming national policies through Andean litigation. Yet even if such cases are filed, it is unclear whether national courts-which have thus far refrained from enforcing Andean rules outside intellectual property - will agree to refer cases to the ATJ or to serve as domestic compliance constituencies for its rulings. ${ }^{237}$

Nevertheless, a more fundamental obstacle may prevent such spillovers from occurring. The ideological differences that divide the member states are greater now than at any time since the

\footnotetext{
${ }^{236}$ For example, 72 percent of the docket of the European Court of Human Rights concerns "access to justice" issues. Cichowski, supra note 235, at 65.

237 We predict, however, that the region's domestic IP agencies will continue to follow Andean IP rules, as the Venezuelan agency SAPI has done even since the country's withdrawal from the Andean Community in 2006. See supra text at note 184.
} 
Andean Pact's founding. ${ }^{238}$ These schisms have hampered efforts to adopt new regional laws and enabled the United States to negotiate with Andean countries bilaterally. ${ }^{239}$ In these oneon-one settings, the United States possesses far greater leverage to pressure each country to adopt policies that favor American interests.

On the other hand, the Andean Community and Mercosur have proposed merging their two regional trade blocs into a single South American Community of Nations. ${ }^{240}$ The blueprint for this union is still in the early drafting stage. But if such a community is formed, its members will probably establish common IP rules and, more important, a tribunal or dispute settlement body to interpret those rules and other regional legislation. ${ }^{241}$ Depending upon which institutions and rules the member countries adopt and how those institutions and rules are linked to national legal systems, the IP rule-of-law island in the Andean Community may expand to include the entire continent.

238 See, e.g., Warren Bull, World View Divides Andean Neighbours, BBC NEWs, Mar. 3, 2008, at< http://news. bbc.co.uk/2/hi/americas/7274209.stm $>$.

${ }^{239}$ For example, the most recent Andean IP legislation, Decision 689, adopted in August 2008, gives individual member states greater leeway to revise domestic IP protection standards. Colombia and Peru advocated a Decision that would allow them to adopt IP protection rules mandated in bilateral free trade agreements that they had negotiated with the United States. Bolivia opposed the dilution of regional IP standards but was outvoted by the other three member states. It has since threatened to file a noncompliance suit with the ATJ. See Erin Kelechava, Andean IP Changes Allow Peru to Sign US FTA, MANAGING InTELL. PrOP., Aug. 28, 2008, available at < http://www. managingip.com/Article.aspx?Article ID $=2034179>$.

${ }^{240}$ South American Community of Nations, at <http://www.comunidadandina.org/INGLES/sudamerican. $\mathrm{htm}>$. For a more detailed discussion of the merger and some of the complications it raises, see Arieti, supra note 192 , at $762-65$.

${ }^{241}$ A former president of the ATJ has suggested that his court could serve that role. See Ricardo Vigil Toledo, El Tribunal de justicia permanente de la Comunidad andina y el Mercosur, 2006-I ANUARIO, supra note 3, at 653. 